\title{
Os liceus na cidade: o exemplo parisiense $(1802-1914)^{*}$
}

\section{The lycées in cities: the example of Paris (1802-1914)}

\author{
Marc Le Coeur** \\ Tradução de Marcus Levy Albino Bencostta***
}

Ce que la ville me présentait d'abord, pour m'initier à une mécanique sociale plus complexe, c'était une de ses institutions les plus représentatives, une des plus dépaysantes aussi pour un enfant de la campagne: le lycée. ${ }^{1}$

\section{RESUMO}

No século XIX, os liceus experimentam a atenção das cidades que os abrigam, provocando sentimentos ambivalentes, entre a atração e a rejeição. Ao procurar múltiplos recursos, as cidades provocam, com efeito, prejuízos que ameaçam sem cessar a saúde, a segurança e a moral dos alunos, como também o curso de seus estudos. Durante muito tempo, os estabelecimentos sofrem para fazer entender suas reivindicações e devem, então, se adaptar sozinhos ao contexto urbano. Mas pouco a pouco estas relações conflituosas diminu-

* Título original "Les Lycées dans la ville: l'exemple parisien (1802-1914)”. Artigo originalmente publicado no número especial da Revista Histoire de L'Education (L'établissement scolaire. Des collèges d'humanités à l'enseignement secondaire, XVIe-XXe siècles), n. 90, p. 131-167, maio 2001.

** Historiador da Arte. Doutorando em História da Arte na Universidade de Paris I. marc_le_coeur@yahoo.com

*** Doutor em História pela Universidade de São Paulo, professor do Programa de Pós-Graduação em Educação na Área Temática História e Historiografia da Educação/Universidade Federal do Paraná. Pesquisador (Bolsa Produtividade) do CNPq. <marcus@ufpr.br>

1 GRACQ, J. La Forme d'une ville. Paris: J. Corti, 1985. p. 149. 
em: no final do século XIX, após o fracasso do governo em sua tentativa de transportar para o campo os estabelecimentos de internos, a cidade torna-se uma verdadeira associada, com a qual os liceus não hesitam em multiplicar suas trocas. Pelo seu exemplo, o caso dos liceus parisienses ilustra esta lenta evolução.

Palavras-chave: história da educação, culturas escolares, arquitetura escolar.

\begin{abstract}
In the 19th century, lycées experienced ambivalent feelings towards the cities that harboured them, ranging from attraction to rejection. Cities offered many resources to schools, on the other hand they caused threatening damage to the health, safety and moral standards of the pupils, as well as to the course of their studies. For a long time, schools struggled to put forward these conflictual relationships gradually died down. Towards the end of the cities, lycées and cities became real partners with an increasing number of contracts between the two. Because of its exemplary nature, the case of the lycées in Paris illustrate this slow evolution.

Key-words: history of education, schools cultures, school architecture.
\end{abstract}

Como outros edifícios comunitários, tais como os conventos, hospitais, casernas ou prisões, os liceus de Paris desejavam se manter completamente isolados. Durante muito tempo, estes se tornaram estabelecimentos feitos para confinar e separar, onde viviam reclusas importantes populações, infantil e adulta de todas as condições, onde as mulheres foram teoricamente exiladas, à exceção das religiosas da enfermaria e das operárias têxteis, cujas grades das janelas desencorajavam as tentativas de evasão tanto quanto de invasões clandestinas. Nesse sentido, as construções dos liceus foram pensadas de modo a deixar do lado de fora as pessoas estranhas que poderiam perturbar a vida regrada que se levava no seu interior: as famílias dos alunos não conheciam mais que algumas peças que se encontram próximas da rua (escritório da administração, parlatório ou salas de espera, capela e mais raramente salão de festa); uma entrada restrita era destinada aos fornecedores, que era uma parte recuada do estabelecimento onde eram autorizados a entrar somente até o pátio no qual ficavam as cozinhas; uma outra entrada era reservada aos alunos externos que permitia, em princípio, mantê-los à distância de seus colegas internos. 
Os liceus eram microcosmos onde se podiam legitimamente identificar em uma pequena aglomeração urbana, como em um país inteiro, segundo o que se fala, de seu ordenamento ou de sua população escolar, quando é atingida pelas mesmas correntes de pensamento e tocada pelas mesmas inegabilidades que atingem a população francesa. Sob a Monarquia de julho (1830-1848) o diretor Rinn vê assim no liceu Louis-le-Grand, que ele dirigia, "um amontoado confuso de casas formando um vilarejo ou uma cidade com seus belos e seus bairros desagradáveis," ${ }^{2}$ e, mais tarde, o escritor Julien Green, vê no liceu de sua infância, uma França reduzida. ${ }^{3}$

Os liceus aspiravam à autarquia, mas sua prosperidade dependia dos múltiplos recursos que a cidade proporcionava, pois era na cidade que se recrutavam a maior parte de seus efetivos e se aproveitavam da proximidade de estabelecimentos diversos nos quais os alunos tomavam banhos quentes, praticavam natação ou equitação, enviavam suas roupas para as lavanderias e utilizavam algumas salas onde ocorriam cerimônias universitárias (banquete na Saint-Charlemagne, distribuição de prêmios...) que nos liceus, pela falta de lugar, eles freqüentemente não podiam celebrar. Em contrapartida, eles deviam suportar os inconvenientes tipicamente urbanos, que a administração não poderia evitar. Partilhados entre atração e repulsão, os liceus experimentaram em relação à cidade sentimentos ambivalentes.

Até a abertura dos primeiros liceus femininos, por volta de 1880 , Paris era a única cidade francesa a contar com mais de um liceu. ${ }^{4}$ Encontramos reunidos nela todos os problemas que se podiam encontrar nos demais estabelecimentos escolares das circunvizinhanças: dificuldades ligadas à escolha do local, penalizado por uma vizinhança que se suportava, mas que não era a desejada e perturbações produzidas por certos estabelecimentos comerciais do bairro ou pela via pública...

Por mais exemplares que fossem, estas confusões não eram menos exacerbadas, pois a capital acumulava os inválidos. Em Paris, mais que em outros lugares, a saúde, a segurança e a moralidade dos alunos, assim como o bom andamento de seus estudos foi exposto a ameaças exteriores, o que

2 Rapport du proviseur Rinn, c. 1846, Archives du Lycée Louis-le-Grand.

3 GREEN, J. Jeunes années. Autobiographie I. Paris: Le Seuil, 1984. p. 77.

4 A primeira cidade da província a dispor de dois estabelecimentos distintos foi Montpellier, cujo liceu de meninas, em funcionamento em 1881, foi oficialmente criado em 18 de janeiro de 1882 . Dois anos mais tarde, o governo autorizou a criação de um segundo liceu de meninos em Lille (decreto de 3 dez. 1883). 
tornava indispensável aos estabelecimentos uma vigilância incessante de seus acessos e uma grande capacidade de adaptação. Pouco a pouco, os contínuos conflitos urbanos perderam espaço para uma relação pacífica, fundada sobre uma melhor compreensão recíproca, um eco à mutação da instituição escolar (nela mesmo). Assim se verá uma abertura progressiva dos liceus nas cidades, antecipando ou seguindo a evolução das práticas pedagógicas, a aparição de novos ensinamentos e o abrandamento da disciplina. ${ }^{5}$

\section{Uma distribuição eqüitativa?}

Ainda que seus edifícios fossem mantidos pelas comunidades onde estavam estabelecidos, ${ }^{6}$ os liceus não tinham vocação para atender uma clientela exclusivamente local. Não havia nenhuma obrigação das famílias viverem próximas aos estabelecimentos que seus filhos freqüentam, mesmo tendo sido o enclausuramento de alunos quase sistemático até o final do século $\mathrm{XIX}^{7}$ e que o aparecimento e depois o desenvolvimento dos transportes ferroviários em pouco tempo favoreceram os deslocamentos de uma vila à outra. "Dos campos, das estações de trem e das pequenas cidades, vê-se, atrás de mim, e bem rápido, a cidade avança, da boa cidade ao liceu diante da qual se escapam os campos, as estações, as pequenas cidades," escreve assim o jovem narrador de La Mère et l'enfant ( $A$ mãe e o filho), lembrando da viagem de trem que o conduzia a sua primeira reentrada escolar. ${ }^{8}$ Embora eles pertencessem a uma vasta rede nacional, estes estabelecimentos foram agrupados no conjunto ur-

5 Sucessivamente liceus, colégios reais ou liceus imperiais, os estabelecimentos parisienses têm freqüentemente mudado de identidade. Nós nos esforçamos aqui de somente conservar o nome atual de cada um deles. O leitor encontrará em anexo a lista de suas denominações sucessivas.

6 Lei do 11 floréal ano X (1 de maio de 1802), artigo 40.

7 As crianças que não eram hospedadas nos liceus o eram nas pensões privadas que povoavam os arredores. Os externos foram durante muito tempo minoria.

$8 \quad$ PHILIPPE, C-L. La Mère et l'enfant 1900. Paris: Gallimard, 1983. p. 7. Reedição. A ação se passa em outubro de 1886 e a cidade em questão é Montluçon (Allier), cujo liceu foi inaugurado três anos antes. 
bano, onde formavam um todo que se entrecruzava com as vias e as malhas ferroviárias, conglomerando-se ano após ano.

As instituições escolares parisienses atraiam grande parte da atenção dos sucessivos governos que tiveram um cuidado caracteristicamente elitista e cosmopolita de seu público. Elas não eram submetidas a nenhuma circunscrição francesa de administração urbana (paroquial ou distrital). Somente nestes casos a administração não levou em consideração a demografia, à despeito das numerosas relações que se referem a tais exemplos. A questão do número e dos locais onde seriam construídos os liceus parisienses se colocava de maneira singular, mas em termos que variavam ao gosto dos regimes políticos e das necessidades, faltando um regulamento que instituísse de uma vez por todas estas questões. $\mathrm{O}$ estudo de sua distribuição na cidade revela uma página inédita do reordenamento de Paris no século XIX.

\section{O Quartier latin, o Sinai do ensino universitário 9}

Às vésperas da Revolução Francesa (fim do século XVIII), Paris contava com 10 colégios em pleno funcionamento, que foram construídos à margem esquerda do Rio Sena: os colégios de Harcourt, do CardinalLemoine, de Navarre, de Montaigu, de Plessis, de Lisieux, da La Marche, dos Grassins, de Louis-le-Grand e dos Quatre-Nations (ou colégio Mazarin). À exceção do último, todos os demais costeavam ao norte da montanha Sainte-Geneviève, entre o Rio Sena e o subúrbio de Philippe-Auguste, formando um conjunto compacto de estabelecimentos que ligavam um labirinto de ruelas tortuosas e íngremes (mapa 1). Ainda que desagradassem muitas famílias, o número elevado e o acúmulo dos colégios tiveram apoio no seio da universidade que procurava perpetuar os limites seculares do Quartier latin e se opunham a todo o reordenamento das Casas de Instrução.

9 Ch. de Rémusat,1845, apud: DOUARCHE, A. L'Université de Paris et les Jésuites (XVIe et XVIIe siècle). Paris: Hachette, 1888. p. 4. 


\section{MAPA 1 - OS COLÉGIOS PARISIENSES EM 1793}

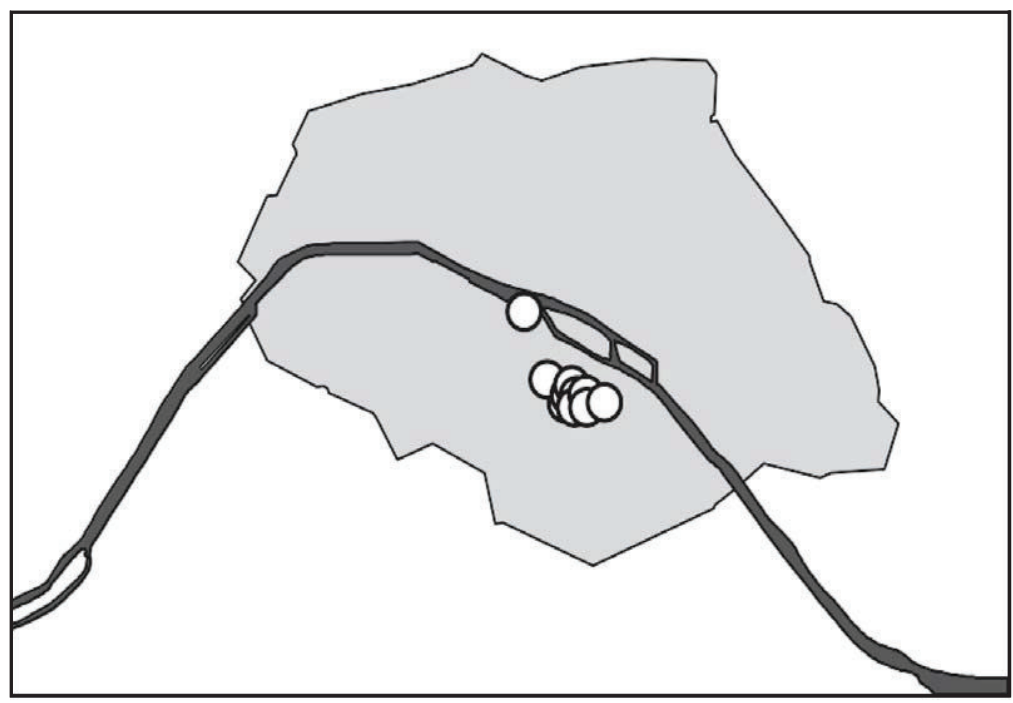

FONTE: LE COEUR; VERNES, 2001.

NOTA: O arredor dos Fermiers-Généraux (1784-1787) circunscreve Paris até $1^{\circ}$ de janeiro de 1860. Neste dia os limites da capital serão recuados até o arredor de Thiers, longo anel fortificado elevado de 1841 a 1844 .

Nos anos de 1760, vários projetos que previam a criação de novos estabelecimentos à margem direita do Rio Sena fracassaram, assim como ocorreu a mudança do Colégio de Lisieux para o bairro do Bastille, nos edifícios da maison-professe, recém deixados pelos jesuítas que foram expulsos da França. ${ }^{10}$ Todavia, no 19 de maio de 1789, atendendo ao desejo da população parisiense, a corporação de mestres apresentava queixas aos Estados Gerais para a transferência de alguns colégios em pleno funcionamento para bairros distantes do centro universitário. ${ }^{11}$ Colocados todos os obstáculos, o desmantelamento do Quartier latin foi, daquele momento em diante, inelutável.

10 BOUQUET, H. L. L'Ancien collège d'Harcourt et le lycée Saint-Louis. Paris: Delalain Frères, 1891. p. 402-403 e 412-413.

11 L'Université de Paris, la Sorbonne et la Révolution. Paris: Fondation FranceLibertés/Chancellerie des Universités de Paris, 1989. p. 71. 
Nos projetos de reforma do sistema educativo, estudado sucessivamente a partir de 1791, aparecia rapidamente que todos os estabelecimentos de Paris não teriam sido conservados. Alguns meses após a supressão dos colégios sobre todo o território da República (15 de setembro de 1793), a comissão de instrução nacional do departamento de Paris cansada de esperar um plano de educação nacional que tardava a ser adotado, decide substituí-los provisoriamente por cinco institutos, assim como havia inutilmente proposto Condorcet um ano e meio antes. Mas este projeto somente atenuava as imperfeições do antigo dispositivo: reduzia-se pela metade o número de estabelecimentos, não se determinava nenhum local novo; ${ }^{12}$ além do mais, se contrapunha a Convenção Nacional que, procurando organizar a unidade do ensino em toda a República, recusava-se a aprovar as iniciativas locais. Enfim, as leis da 7 de ventôse $e^{*}$ ano III (25 de fevereiro de 1795) e 3 de brumaire $^{* *}$ ano IV (25 de outubro de 1795) criava escolas centrais na proporção de uma escola por departamento $^{* * *}$ e atribuía somente cinco para a cidade de Paris.

Das escolas centrais... aos liceus centrais

Com o objetivo de preservar as finanças da República, dois fatores principais determinaram a escolha dos locais que acolheriam as escolas centrais: designar os edifícios nos quais a disposição e o estado geral permitissem uma adequação rápida e pouco dispendiosa, entretanto, se deveria encontrar, junto a cada escola, uma biblioteca pública, um jardim e um laboratório de história natural, um laboratório de química e de física experimental, recursos dos quais dispunham poucos dos antigos colégios. Em Paris, como na maioria das cidades dos departamentos, as pesquisas indi-

12 Os referidos institutos que sucederiam os colégios dos Quatre-Nations, de Harcourt, de Louis-le-Grand, de Navarre e do Cardinal-Lemoine.

* Sexto mês do calendário republicano francês. N.T.

** Segundo mês do calendário republicano francês. N.T.

*** Divisão administrativa do território francês sob a autoridade de um comissário da República. N.T. 
cam centenas de propriedades confiscadas do clero, dos imigrantes ou da realeza, desde o início da revolução.

De fato, a primeira lista de locais que foi proposta para Paris desprezava os edifícios escolares da montanha Sainte-Geneviève ( 8 de messidor ${ }^{*}$ ano III / 26 de junho de 1795): para a instalação de quatro escolas projetadas, sendo os locais confiscados das antigas congregações religiosas os preferidos, e o edifício dos Quatre-Nations reencontraria sua vocação inicial (mapa 2). De maneira a facilitar o acesso a todos os pontos da cidade, os quatros novos locais reunidos balizaram o percurso da chamada Cruzada de Paris, seja do sul ao norte, sob o traço do antigo cardo da Lutèce primitiva (Ruas Saint-Jacques e Saint-Martin): abadia de Val-de-Grâce e o priorado de Saint-Martin des Champs; ao oeste e a leste, contornando as Ruas Saint-Honoré e Saint-Antoine: o convento das Filles de la Conception e a maison-professe dos Jesuítas (ou na falta, o convento das Minimes, atrás da

\section{MAPA 2 - AS ESCOLAS CENTRAIS PARISIENSES DE 1795 A 1803}

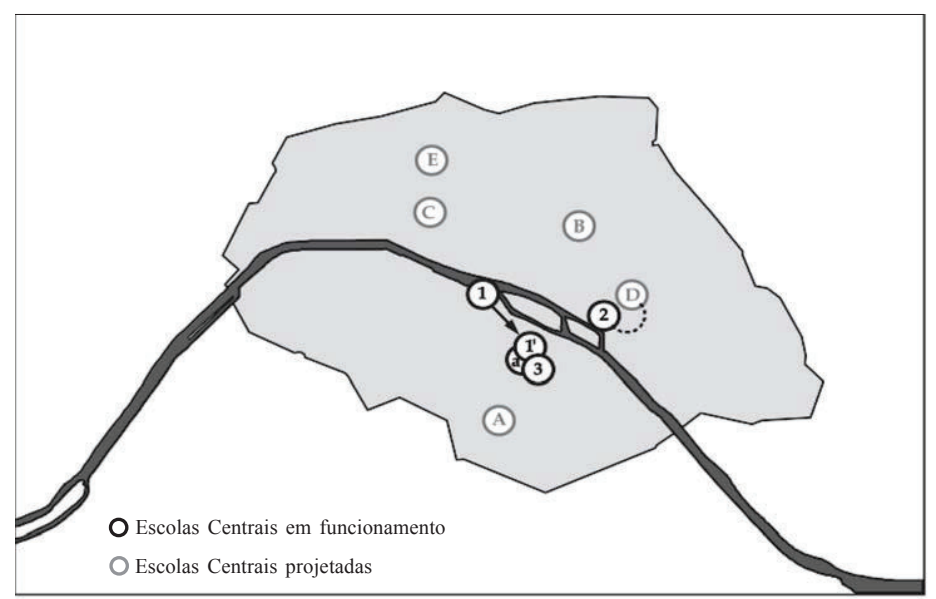

FONTE: LE COEUR; VERNES, 2001.

NOTA: a, Institut des Boursiers / Prytanée français; 1, Ecole centrale des Quatre-Nations; 1', Ecole centrale du Plessis; 2, Ecole centrale de la rue Saint-Antoine; 3, Ecole centrale du Panthéon; A, Abbaye du Val-de-Grâce (1795); B, Prieuré de Saint-Martin des Champs (1795 et 1799); C, Couvent des Filles de la Conception (1795); D, Couvent des Minimes (1795); E, Couvent des Capucins (1798).

* Décimo mês do calendário republicano francês. N.T. 
praça des Vosges). Além disso, tentava-se suprimir as fronteiras da antiga Universidade de Paris, sendo que esta nova divisão encerrava o arcaico monopólio da margem esquerda do Rio Sena, na qual se encontravam somente duas escolas contra três sobre a populosa margem direita do Rio Sena; quanto ao despovoado Quartier latin, este conservou o Instituto des Boursiers, estabelecimento que dois anos antes sucedeu o colégio Louis-le-Grand. ${ }^{13}$

Apesar de sua virtude, este plano não foi adotado em sua integralidade. Somente dois dos locais propostos foram finalmente retomados. ${ }^{14}$ Abertas à véspera do verão de 1796, as primeiras escolas centrais de Paris inauguram os edifícios dos respectivos colégios: Quatre-Nations, maison-professe dos Jesuítas (Rua Saint-Antoine), e a abadia de Sainte-Geneviève, atrás do Panthéon; quanto às duas últimas escolas - às quais se destinaram, respectivamente em agosto de 1798 e março de 1799, os edifícios do Convento dos Capuchinhos, em Chaussée d'Antin, e uma parte do priorado de Saint-Martin des Champs ${ }^{15}$ -, estas permaneceram apenas como projetos. Os governos da Convenção (1792-1795) e Diretório (1795-1799) sem perceber, comprometeram e entravaram duramente o futuro do desenvolvimento das escolas centrais e depois dos liceus, ao descaracterizar a única e real tentativa de divisão racional e eqüitativa dos estabelecimentos de instrução parisiense.

Até 1801, apesar de sua proximidade, as três escolas parisienses escaparam ao agrupamento. Localizadas em ângulos de um triângulo imaginário, tendo a Catedral de Notre-Dame por centro e por lados uma distância média de 1500 metros, elas interligavam três bairros distintos - o faubourg Saint-Germain, o Marais e o Quartier latin - de populações bastante diferenciadas. Contudo, a transferência da escola de pintura, escultura e arquitetura do edifício dos Quatre-Nations em 19 de vendémiaire, ${ }^{*}$ ano X (11 de outubro de 1801), resulta no precoce deslocamento da mais importante dentre elas para o antigo Colégio de Plessis (Rua Saint-Jacques), para o prejuízo de seus professores. Ainda que o faubourg Saint-Germain tivesse perdido definitivamente seu único estabelecimento de ensino público, o Quartier latin recuperou sua supre-

13 Sob suas sucessivas apelações, o colégio Louis-le-Grand foi o único estabelecimento de instrução francesa a não ter jamais fechado suas portas.

14 Mal lembrado, a escolha do Val-de-Grâce foi rapidamente rejeitada. Esta antiga Abadia não era julgada suficientemente central.

15 A maior parte do antigo priorado de Saint-Martin des Champs foi atribuído ao Conservatório de Artes e Ofícios em 10 de junho de 1798.

* $\quad$ Primeiro mês do calendário republicano francês. N.T. 
macia: duas escolas centrais sob três vizinhas ao Quartier latin, doravante com o Prytanée français, precedendo o Instituto des Boursiers.

A abertura dos primeiros liceus parisienses em 1803 e 1804 confirmava este novo desequilíbrio entre os bairros de Paris. Diante dos recursos originários de fundos nacionais terem sido consideravelmente reduzidos, a construção de edifícios destinados especificamente ao uso escolar nem sempre foi uma questão prioritária. Os novos estabelecimentos foram simplesmente subsituados em casas de educação já existentes, tais como, o atual liceu Louis-le-Grand que, na montanha de Sainte-Geneviève, substitui o Prytanée français e a escola central de Plessis, e o atual liceu Henri IV, escola central do Panthéon. Do outro lado do Rio Sena, no bairro do Marais, o liceu Charlemagne sucede a escola central da Rua Saint-Antoine e, ao noroeste de Paris, o atual liceu Condorcet investiu nos locais que deveriam ocupar a escola central (somente projetada), da Chaussée d'Antin (mapa 3).

MAPA 3 - OS LICEUS PARISIENSES DE 1803 A 1879

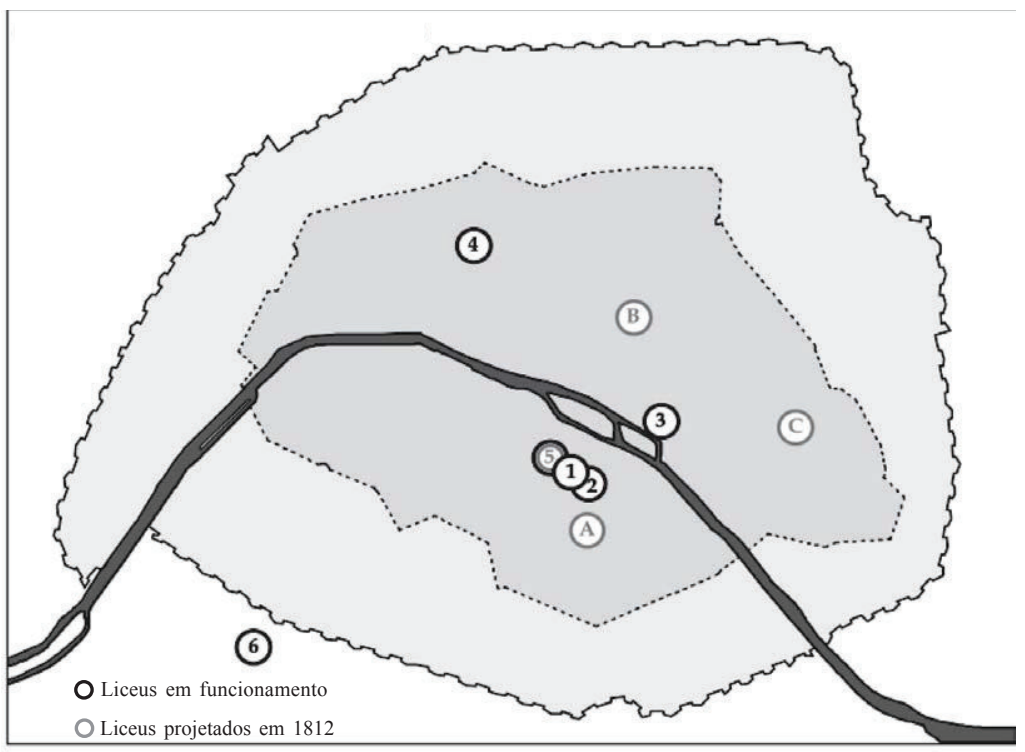

FONTE: LE COEUR; VERNES, 2001.

NOTA: (De 1 a 6 ver abaixo...) A, Pensionnat Parmentier; B, Prieuré de Saint-Martin des Champs; C, Maison Sainte-Croix. 


\section{Uma tentativa de reequilibrar o leste parisiense}

Após alguns anos, parecia que o número de quatro liceus não respondia mais as necessidades da população parisiense, tanto que os dois estabelecimentos da margem direita do Rio Sena acolhiam somente externos. ${ }^{16}$ Em 1809, contava-se 1792 alunos em Paris; em 1812 eram 3681 alunos, dos quais 937 eram pensionistas, número muito elevado e que jamais as escolas centrais alcançaram. Em conseqüência do decreto de Napoleão, de 15 de maio de novembro de 1811, foram estabelecidos mais quatro novos liceus em Paris, ${ }^{17}$ sem contudo, apresentar nenhum local, o que provocou pela primeira vez um afluxo de sugestões espontâneas de chefes de instituições ou de simples particulares que atestavam a importância da abertura. A administração, cuidadosa sem dúvida, de sua imparcialidade não aceitou nenhuma das proposições, determinando somente os locais onde seriam estabelecidos os liceus suplementares e definindo assim, um novo plano conjunto que tentava corrigir as imperfeições do dispositivo inicial em benefício do leste parisiense (decreto de 21 de março de 1812).

Os edifícios destinados à margem esquerda do Rio Sena foram o antigo Colégio de Harcourt, Rua da Harpe (Boulevard Saint-Michel) e o pensionato Parmentier, Rua dos Postes (Lhomond); da margem direita, o antigo priorado de Saint-Martin des Champs, que liberava o conservatório das Artes e Ofícios e a casa Sainte-Croix, Rua de Charonne. Mas a restauração (1814-1830) minou em pouco tempo o projeto imperial: dos liceus projetados, somente o liceu de Harcourt viu o dia em que foi posto em atividade como Colégio Real de Saint-Louis, em outubro de 1820, a uma pequena distância do Louis-le-Grand.

E depois? Nada mais aconteceu até a chegada do Ministro Jules Ferry e sua equipe, em 1879. Durante sessenta anos, os parisienses não tiveram outra escolha senão empilhar seus filhos em alguns liceus ou, após 1850,

16 Na realidade, a despeito dos projetos da administração, os liceus Charlemagne e Condorcet ficaram durante várias décadas sendo os únicos liceus franceses a não ter pensionato.

17 Mais amplamente, este decreto aumenta o número de liceus até cem em toda a extensão do Império. 
enviá-los aos estabelecimentos particulares (laicos ou religiosos) que proliferaram em Paris. ${ }^{18}$

\section{A inércia dos prefeitos}

Com seus cinco liceus intramuros, o século XIX não fez melhor que Antigo Regime: a margem direita do Rio Sena definitivamente penalizada e a maior parte do oeste de Paris desprovida de estabelecimento de instrução pública, uma situação incômoda que se agravava ainda mais com o crescimento da cidade pela incorporação das comunas suburbanas, feita em $1^{\circ}$ de janeiro de 1860. Apesar da existência de novos colégios reais e liceus, ${ }^{19}$ os estabelecimentos suplementares foram reivindicados aos vereadores, mas os iminentes apelos da população ou dos governantes ficaram sem efeito.

Uma obra posta a crédito do II Império (1852-1870) trouxe à atenção para uma modesta melhora: em 1864, Napoleão III pronunciava a liberação do anexo campestre do liceu Louis-le-Grand a setecentos metros do porte de Versailles tornando-se, enfim, um estabelecimento autônomo: o liceu Michelet em Vanves. Mas em Paris, as lacunas perduravam, pois não era a hora para a multiplicação dos estabelecimentos.

De todos os prefeitos do Seine, o barão Haussmann foi sem dúvida o mais criticado, o que não esboçou a criação de nenhum novo liceu, a despeito das exortações do ministro e do vice-reitor da Academia de Paris, ${ }^{20}$ não obstante a um contexto propício a construção de grandes edifícios públicos, a metamorfose de Paris não chega aos liceus.

Haussmann se contentou em aumentar os liceus Saint-Louis, Henri $I V$ e Condorcet e determinou a mudança para um novo local, porque as constituições de estabelecimentos escolares tornaram-se obrigatórias de

18 Cf. HUGUET, F. Les pensions et institutions privées d'enseignement secondaire pour garçons, dans la région de l'Île de France, du XVIIIe siècle à la fin de la Troisième République. Histoire de l'éducation, n. 90, p. 205-221, maio 2001.

19 Ratificando uma disposição de 1841, a Lei de 15 de março de 1850 estipulou que toda cidade que quer obter a criação de um liceu deve arcar com as despesas de construção e da apropriação requeridas para este fim.

20 As funções de reitor da academia de Paris serão exercidas pelo ministro da Instrução. 
modo impreterível. Uma despropositada saída resultou em um de seus raros fracassos pessoais: transferiu o colégio Rollin (atual liceu JacquesDecour) do Quartier latin e o colégio Chaptal ${ }^{21}$ para o oeste da cidade, porém, teve que renunciar o deslocamento do liceu Louis-le-Grand para as proximidades do faubourg Saint-Germain, diante dos protestos de seus exalunos, que se opuseram violentamente a esta extirpação. ${ }^{22}$

\section{A corrida em direção ao oeste}

Uma nova época se inaugurava com chegada ao poder dos republicanos, cujo ponto de partida foi a curta relação que imprimiu Octave Gréard, em abril de 1879, algumas semanas após sua nomeação como principal líder da Academia de Paris. ${ }^{23}$ Após ter condenado a insuficiência, o superpovoamento e a ruína dos liceus de Paris, o vice-reitor reivindicava a necessidade imediata da reconstrução do Louis-le-Grand, a construção do futuro liceu Janson-de-Sailly, ${ }^{24}$ a criação de três novos liceus - à leste da cidade (Avenida de la République), à noroeste (na XVII Circunscrição Administrativa) e a sudoeste (na XV Circunscrição Administrativa) - e a ampliação do liceu Saint-Louis.

Contrariamente aos projetos abortados de 1795 ou de 1812, a execução deste novo plano desta vez foi integralmente retomada nos anos se-

21 Elevados ao norte de Paris, ao longo do antigo cinturão dos Fermiers Généraux, os edifícios destinados a abrigar esses dois estabelecimentos municipais serão concluídos apenas dez anos mais tarde.

22 O local destinado era aquele do hospício dos Incuráveis (mulheres) da Rua de Sèvres, destinado mais tarde ao hospital Laënnec (Cf. LE COEUR, M. Le lycée Louis-leGrand à Paris: chronique d'une reconstruction différée (1841-1881). Histoire de l'art, n. 23, p. 71, oct. 1993).

23 GRÉARD, O. Note sur les besoins de l'enseignement secondaire à Paris. Não datado [30 de abril de 1879].

24 Único liceu parisiense a não ser dedicado a uma glória nacional, o liceu Jansonde-Sailly traz o nome de um rico advogado parisiense que, perto de 50 anos antes, havia instituído a universidade sua herdeira universal com a condição de criar em Paris uma instituição sob o nome de colégio Janson. Sua construção, autorizada desde 1876, começou a funcionar somente em 1881 . 
guintes por Jules Ferry e seus sucessores, em colaboração com a cidade de Paris: aos novos liceus de meninos se juntaram os liceus das meninas, em ampliação à lei de 21 de dezembro de 1880 .

A rapidez com a qual foram empreendidos os trabalhos deixava de corresponder à impaciência do governo: à partir de 1882, um novo estabelecimento abria as portas a cada ano escolar, sendo que alguns deles conseguiram distribuir melhor o número de alunos entre os liceus existentes, de tal modo que o número de liceus parisienses triplicou entre os anos de 1879 e 1914 (mapa 4).

MAPA 4 - OS LICEUS PARISIENSES DE 1879 A 1914

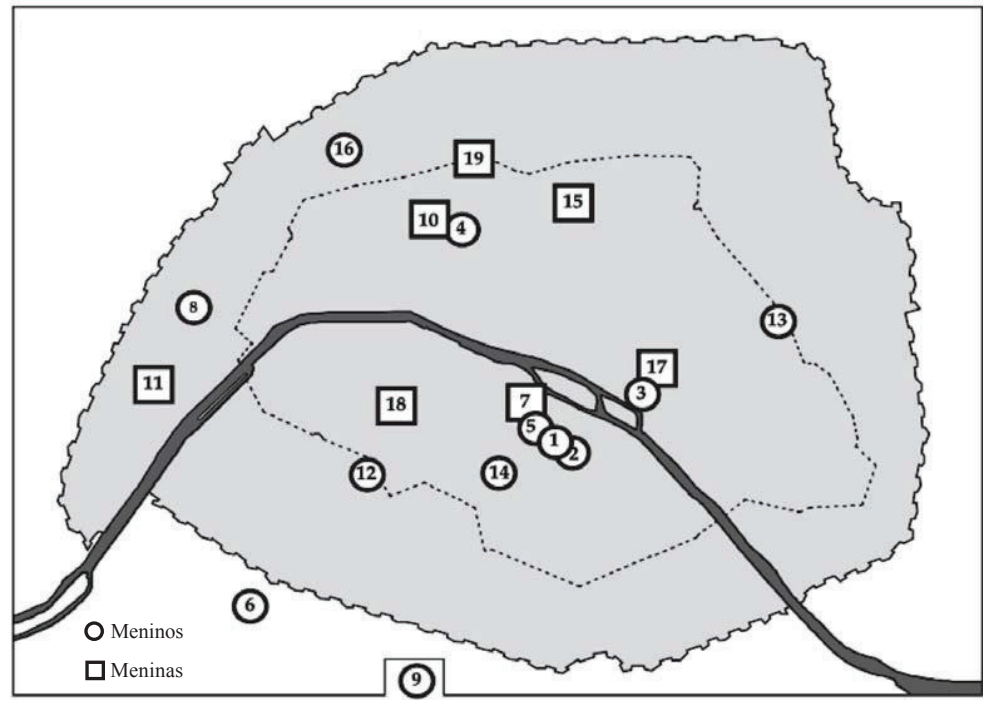

FONTE: LE COEUR; VERNES, 2001.

NOTA: 1, Louis-Le-Grand; 2, Henri IV; 3, Charlemagne; 4, Condorcet; 5, Saint-Louis; 6, Michelet (Vanves); 7, Fénelon; 8, Janson-de-Sailly; 9, Lakanal (Sceaux); 10, Racine; 11, Molière; 12, Buffon; 13, Voltaire; 14, Montaigne; 15, Lamartine; 16, Carnot; 17, VictorHugo; 18, Victor-Duruy; 19, Jules-Ferry. 
A divisão dos liceus de meninos foi tal que preocupou mais ainda a administração, pois não se tratou somente de retomar o atraso da cidade em matéria de ensino secundário público, desde várias décadas, ${ }^{25}$ mas sobretudo, de lutar contra a hegemonia que exerciam as casas de educação religiosas nas Circunscrições Administrativas a oeste de Paris. ${ }^{26}$ Os liceus fundados (Janson-de-Sailly, Buffon e Carnot), cujos locais respondiam a este imperativo político, mais que um estudo estatístico das reais necessidades dos parisienses foi uma tentativa de lutar contra os estabelecimentos religiosos que se encontravam nesta região, da mesma forma o liceu Lakanal que foi criado em Sceaux, neste subúrbio do sul da cidade onde já prosperavam vários estabelecimentos particulares. Somente um liceu foi criado à leste da cidade (liceu Voltaire), na fronteira de duas Circunscrições Administrativas bastante povoadas, mas onde não existia nenhuma ameaça congregacionalística (a XI e a XX Circunscrições Administrativas). A localização dos liceus de meninas apresentou menos problemas, pois cada um deles foi colocado de preferência próximo a um liceu de meninos $^{27}$ e, a exceção do liceu Molière, nas Circunscrições Administrativas centrais de Paris (IV, VI, VII, VIII e IX).

25 Em 1880, Jules Ferry observou que "Paris é certamente a cidade da França que teve cuidado com a população e sua extensão, apresentou menos recursos para o ensino secundário público" (Cf. FERRY, J. Carta a Ferdinand Herold, prefeito do Sena. Paris, 04 abr. 1880). De 1870 a 1914, mais de 300 novas escolas foram igualmente construídas (Cf. CHÂTELET, A-M. La Naissance de l'architecture scolaire. Les écoles élémentaires parisiennes de 1870 à 1914. Paris: Honoré Champion, 1999. p. 7). Na mesma época, a maioria dos estabelecimentos universitários parisienses é ampliada ou reconstruída.

26 "Um grande número de pais, mesmo aqueles dentre eles que preferiam o ensino público, é obrigado a confiar seus filhos aos estabelecimentos livres, na impossibilidade de onde se encontravam de procurar o liceu a cinco, seis e até oito quilômetros. Não estaria longe da verdade afirmar que com esta situação excepcional e escolha de um bairro deserto que alguns estabelecimentos congregacionistas devem uma parte de seu sucesso" (FERRY, 1880).

27 O primeiro dentre eles (Fénelon) foi naturalmente fundado no Quartier latin, próximo do Saint-Louis, do Louis-le-Grand e do Henri IV; Racine, depois Jules-Ferry se elevam não longe de Condorcet e do Carnot; Lamartine vizinho ao colégio Rollin; Molière, com Janson-de-Sailly; Victor-Hugo, com Charlemagne; Victor-Duruy enfim, com Buffon. 
Preciosos auxiliares: os transportes urbanos

A multiplicação e disseminação dos liceus constituíram um progresso indubitável, mas os critérios de divisão adotados engendraram um novo desequilíbrio em detrimento das circunscrições administrativas populares que circundavam a cidade ao norte, à leste e ao sul (XVIII, XIX, XX, XII, XIII e XIV Circunscrições Administrativas), vasto território onde a municipalidade concentrava simultaneamente uma parte das escolas primárias superiores e a quase totalidade das escolas profissionais. Todavia, seria abusivo falar da segregação geográfica ou social, pois, no momento que o regime de internato conheceu um crescente declínio, a escolha dos locais mais distantes do centro da cidade foi determinada pela facilidade e rapidez das vias de transporte: proximidade dos grandes eixos de circulação, ${ }^{28} \mathrm{de}$ transporte em comum ou de uma linha férrea que alargava as zonas de acesso até os bairros circunvizinhos e mesmo às comunas da periferia, assim como já acontecia com o liceu Condorcet. ${ }^{29}$ Os liceus Janson e o Molière se beneficiavam das linhas férreas que os circundavam e as linhas de bonde que religavam as antigas comunas de Passy e de Auteuil ao centro de Paris; Lakanal foi implantado no trajeto da linha de Sceaux; $;^{30}$ Buffon foi construído nas vizinhanças da Estação de Montparnasse, assim como havia solicitado Jules Ferry, em 1880.

28 Como os colégios Chaptal e Rollin alguns anos antes, os liceus Buffon, Voltaire e Jules-Ferry foram construídos nos limites dos antigos boulevards exteriores. Carnot se elevava entre o Boulevard Malesherbes e a Avenida de Villiers; Janson apresentava uma fachada sobre a Avenida Georges-Mandel.

29 Em razão de sua proximidade com a estação Saint-Lazare, o Condorcet se tornou em alguns anos o mais populoso dos liceus parisienses: em 1841, contava com mais de mil alunos, chegando a 1600 em 1879.

30 Os jovens ou suas famílias embarcavam na Praça Denfert-Rochereau, onde um café tem até hoje o nome "Lakanal", mesmo que a localização tenha obrigado o estabelecimento a não receber mais os pequenos parisienses, eles desciam na estação Bourg-la-Reine, depois seguiam a pé até a Avenida "do Liceu Lakanal" que os levava diretamente à porta do estabelecimento. A linha de Sceaux foi prolongada até Luxembourg em 1895, o que beneficiou os liceus do Quartier latin. 
Então, a principal dificuldade não foi a distância do domicílio familiar, mas a demora e a duração dos trajetos que as crianças e os adolescentes deviam freqüentemente aprender a percorrer sozinhos. ${ }^{31}$

A despeito de um aumento constante no número de alunos dos liceus e da concomitante lentidão na construção de estabelecimentos na cidade - nenhum liceu foi fundado em Paris entre 1895 (Victor-Hugo) e 1912 (VictorDuruy) -, esta mensagem escolar funcionou tão bem que mal eclodiu a I Guerra Mundial, no dia seguinte, a superpopulação escolar impôs uma nova campanha de construções em Paris, o que foi novo nas comunas periféricas. Então, somente aparecerá a necessidade de colocar a localização e a quantidade de liceus em relação com a população. Com uma clientela cada vez mais local, os liceus se tornaram rapidamente em simples instalações necessárias ao bairro, desmentindo assim o pressentimento de Jules Verne, que imaginava que em 1937 seria criado um gigantesco estabelecimento - a Sociedade Geral de Crédito Instrucional [sic] - centralizando a educação da França integra sobre um lugar único: o Champ-de-Mars $!^{32}$

\section{A cidade hostil}

Até a Monarquia de Julho, a administração esteve mais preocupada com o conteúdo do ensino e a conduta dos alunos que com distribuição interior dos estabelecimentos. Na falta de textos definindo precisamente a natureza dos locais que deveriam abrigar um liceu, somente um conheci-

31 Um certo número de mães de família receava esta precoce autonomia de suas crianças, assim como escreve o jovem narrador do Diable au corps: “...Minha mãe me achava muito novo para ir ao Henri IV. Na sua cabeça isso queria dizer: para pegar o trem. Eu fiquei dois anos em casa e trabalhava sozinho" (RADIGUET, R. Le Diable au corps. 1923. Paris: Le Livre de Poche, 1981. Reedição, p. 12). Da mesma forma, Julien Green (nascido em 1900) recorda da longa viagem que ele devia fazer com 13 anos para retomar do Liceu Janson-de-Sailly depois Le Vésinet (pequena cidade nos arredores oeste de Paris) onde sua família acabara de mudar: primeiro uma hora de trem até a estação Saint-Lazare, depois o caminho de ferro até a Avenida Henri-Martin. E Green conclui: Esta viagem, eu fazia sozinho e era isso que assustava minha mãe. (GREEN, op. cit., p. 125).

32 Cf. VERNE, J. Paris au XXe siécle (1863). Paris: Hachette/Le Cherche Midi, 1994. p. 29-34. 
mento gradual das necessidades permitiu então, corrigir os defeitos da organização inicial e reduzir suas carências.

Fundado, primeiramente sobre tentativas empíricas, a organização material dos liceus se racionalizou lentamente até originar uma nova tipologia arquitetural que combinava as exigências da pedagogia, da higiene e da disciplina. Foi um ponto, no entanto, que os diretores dos liceus e os arquitetos cuidaram para organizar completamente o reordenamento urbano. Freqüentemente perniciosa, doentia, sediciosa, ruidosa e propícia aos acidentes de toda sorte, a cidade era uma adversária contra qual os estabelecimentos escolares deveriam aprender a se prevenir.

\section{Uma vizinhança indesejável}

As condições de instalação dos primeiros liceus foram muito heterogêneas. A configuração e a dimensão das áreas, a disposição e o estado geral dos edifícios, o número e a superfície dos pátios e jardins variavam muito de um estabelecimento para outro.

Durante muito tempo, a forma como os liceus abrigavam seus alunos apresentava uma única característica. O liceu Louis-le-Grand não passava de um aglomerado de construções díspares e terrivelmente arruinados, que dominavam pátios sombrios e úmidos onde pobres árvores penam para desabrochar; ${ }^{33}$ o liceu Henri $I V$, ao contrário, era um amplo conjunto arquitetônico harmonioso de grande influência, atrás do qual se estendiam jardins, pomares e um largo terraço arborizado; no liceu Condorcet havia também um jardim precedido por pequenas e recentes construções (1783), que circundavam um único pátio de recreação: o antigo claustro dos capuchinhos; já o liceu Charlemagne era uma construção regular de linhas rígidas, cuja demarcação ao fundo em áreas privava o estabelecimento de uma verdadeira fachada sobre a Rua Saint-Antoine. ${ }^{34}$

33 LE COEUR, op. cit., p. 67-68.

34 Até recentemente, o principal acesso ao liceu Charlemagne consistia em uma longa e estreita passagem bloqueada entre a Igreja Saint-Paul-Saint-Louis e um imóvel, precedido por uma simples grade. Em 1865, ele permanece o menor liceu da França. 
A despeito destas diferenças, todos apresentavam numerosos traços em comum. A maior parte dos liceus franceses ficou por várias décadas constrangida a partilhar seu território com outros estabelecimentos públicos: museus, bibliotecas municipais, locais da justiça de paz, faculdades etc. cuja presença (às vezes no coração mesmo dos estabelecimentos) perturbava a vida escolar e contrariava toda a tentativa de organização racional destes locais. Desse modo, os reitores dos liceus não desistiram e obtiveram a saída destes vizinhos importunos entremeados por pretextos como a segurança dos alunos, a falta de lugar ou a simples regra de convivência. Evidentemente, os liceus de Paris não escaparam a tais sujeições. O antigo Colégio de Plessis, do qual dois terços foram conferidos ao liceu Louis-le-Grand por decreto imperial de 1804, foi ocupado pela Escola Normal e, durante algum tempo, pela Faculdade de Letras e uma seção da Faculdade de Direito; ${ }^{35}$ a Biblioteca de Sainte-Geneviève, mantida

\section{FIGURA 1 - LICEU CONDORCET}

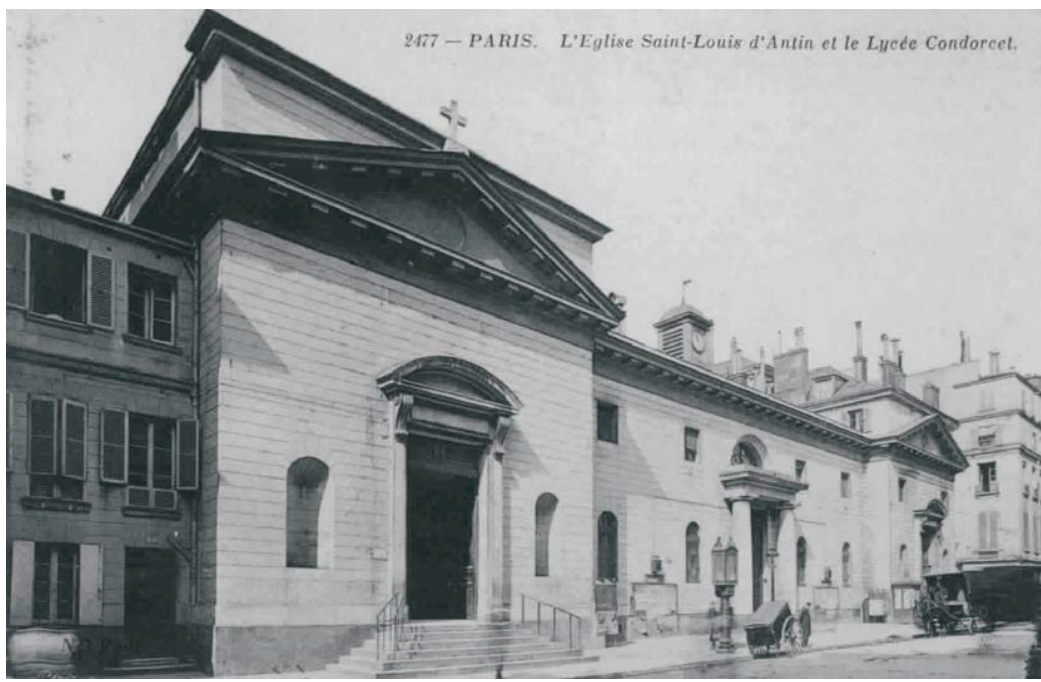

FONTE: COLEÇÃO MARC LE COEUR.

35 Alguns anos antes, durante o período revolucionário, os alunos do Louis-leGrand já tinham que partilhar seus espaços com a metade de um batalhão (1792-1793), depois uma prisão política (1793-1794), uma sala de trabalhos gerais (1794) e, por fim, com o Comitê Revolucionário da sessão do Panthéon (1794) (DUPONT-FERRIER, G. Du collège de Clermont au lycée Louis-le-Grand (1563-1920). Paris: Boccard, 1921. Tome I, p. 328329). 
nesse local após a sua nacionalização em 1790, privou o Liceu Henri IV de um andar inteiro, e a sacristia da Igreja Saint-Paul-Saint-Louis formava um enclave em volta do liceu Charlemagne.

Por quarenta anos, o governo não deu atenção às legítimas reclamações dos liceus parisienses e não decidiu por um fim às queixas que foram geradas pelas várias décadas de coabitações. Em 1839, uma convenção decide o conflito que opunha o liceu Charlemagne e os administradores da igreja adjacente; em 1841, uma lei proclama a mudança da Escola Normal para um edifício novo (Rua $\left.d^{\prime} U l m\right)^{36}$ e, três anos mais tarde, uma outra lei determina a ida da Biblioteca de Sainte-Geneviève para o antigo local que abrigava o Colégio de Montaigu, localizado a duzentos metros do liceu Henri $I V .{ }^{37}$ A coexistência destes atos não foi nem um pouco fortuita: a iniciativa em resposta ao ministro Abel-François Villemain, ao qual se deve também o primeiro texto regulamentando a organização material dos estabelecimentos secundários de ensino. ${ }^{38}$

Por seus locais suscitarem ambições, nos anos seguintes, os liceus tiveram ainda que lutar para não serem pura e simplesmente expulsos. ${ }^{39}$ Quanto a seus contornos, não foram inatingíveis e os mesmos tiveram que se submeter às transformações da cidade, abandonando os pequenos terrenos à Inspeção Geral das Ruas, por vezes em troca de novas áreas. Se o alargamento das vias resultava em pouco proveito para os estabelecimentos, ${ }^{40}$ a abertura de novas

36 A entrega do novo edifício em 1847 levou a transferência da Escola Normal da Rua Saint-Jacques, mas, no dia seguinte ao da Revolução de 1848, o governo a substituiu pela efêmera Escola de Administração. Por esta razão, somente em maio de 1849, o liceu Louisle-Grand ficará de uma vez por todas com o controle dos edifícios do Plessis.

37 A nova biblioteca foi construída entre os anos de 1843 a 1850 por Henri Labrouste. Seus antigos espaços só foram oficialmente reunidos ao liceu Henri IV em 1853.

38 Indication des locaux nécessaires pour l'établissement d'un collège royal. 30 de maio de 1843. Bulletin universitaire, p. 132-134, 1843.

39 Dentre os projetos que nós encontramos, citamos a transferência da Faculdade de Ciências nos edifícios do liceu Saint-Louis (1849) ou sua reconstrução sobre o local do liceu Louis-le-Grand (1879); a construção de uma "basílica monumental" nos terrenos do liceu Condorcet (1853) e a substituição da Escola Politécnica ao Liceu Henri IV (1891). No Primeiro Império, os espaços do liceu Charlemagne foram destinados às missões estrangeiras (1804-1806) e aqueles do liceu Henri $I V$ ao palácio da Universidade e à Escola Normal (1811).

40 Ao final de uma convenção assinada em 1844, o liceu Condorcet sacrificou uma grande parte de seu jardim para permitir o alargamento da Rua Saint-Lazare e o loteamento de seus contornos. Nos anos de 1860, a fachada do liceu Saint-Louis foi cortada em mais de cinco metros para respeitar o alinhamento do novo Boulevard Saint-Michel, que substituiu a estreita e sinuosa Rua da Harpe, seguindo o plano do prefeito Haussmann. 
ruas pôde, ao contrário, se revelar como salutar, como a Rua Clovis (1807), a Rua du Havre (1844) e o último pedaço da Rua de Vaugirard (1910) que permitiram assim a agilidade de acesso parcial dos liceus Henri IV (fachada norte), Condorcet (fachada oeste) $)^{41}$ e Saint-Louis (fachada sul). ${ }^{42}$

Um outro ponto que preocupou muito os liceus foram os imóveis de habitação ou as simples casas ao seu redor, que impediam os raios de sol e abafavam as classes. Pior, certos prédios tinham vistas direto para o interior dos estabelecimentos, o que podia causar serias perturbações. O mais vulnerável dentre todos foi o liceu Saint-Louis, o mais novo e também o mais encravado. ${ }^{43}$ Mestres, domésticos e alunos deviam suportar as provocações e as piadas das prostitutas e dos estudantes que povoavam certos hotéis nos arredores. Não podendo fazer parar estes comportamentos subversivos, a administração decidiu pela colocação de uma grade de cinco metros rente às irregulares fachadas e o plantio adicional de árvores no espaço destinado a recreação.

Isolar-se

Ano após ano, a experiência provou de uma vez por todas todo o interesse que os estabelecimentos tiveram ao seu favor, uma vez por todas da totalidade de uma ilhota. Infelizmente, todo o projeto de desenclavinhação tropeçou freqüentemente nos custos proibitivos das áreas limítrofes e, em

41 A Rua do Havre facilitava o movimento de carros nos arredores da nova estação Saint-Lazare. Simultaneamente à perda de seu jardim (ver nota anterior), o liceu Condorcet foi autorizado a se estender até a nova rua e a abrir uma porta sobre aquela. Vinte anos mais tarde, um verdadeiro edifício foi construído, o mesmo que abriga até hoje a entrada principal do estabelecimento.

42 Em troca dos terrenos que ele devia abandonar, o liceu Saint-Louis obteve o direito de se estender em direção à Rua Racine, sobre o terreno dos antigos reservatórios municipais.

43 O liceu Saint-Louis foi o primeiro de Paris (e um dos primeiros na França) a ter sido especificamente construído para este uso. 
1865, menos de um sétimo dos liceus franceses estavam completamente isolados das construções particulares. ${ }^{44}$

Uma etapa decisiva foi superada com a construção dos novos colégios Chaptal (1866-1876) e Rollin (1866-1877). Pela primeira vez em Paris, estabelecimentos de ensino secundário foram construídos ex nihilo sobre ilhotas quadrangulares, livres sobre todas suas faces; a amplitude do projeto geral, a regularidade e a racionalidade das distribuições, a ponderação das massas e o número e a extensão dos corredores, a multiplicação dos acessos se encaixavam perfeitamente às regras editadas pelo ministério, assim como as prescrições dos higienistas. Chegada à maturidade, a arquitetura escolar encontrou suas primeiras obras-primas modernas.

Como outras construções contemporâneas (os Halles centrais, a nova Ópera), esses dois colégios se tornaram rapidamente modelos que, graças a uma grande difusão da imprensa profissional, suscitou infinitas variantes

FIGURA 2 - LICEU JANSON

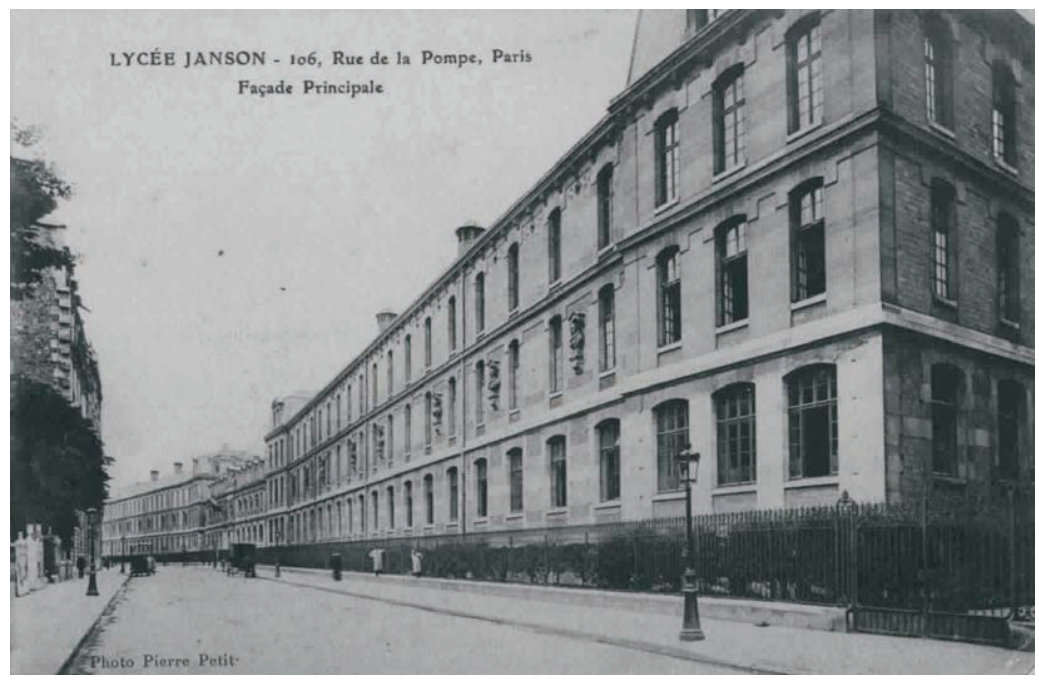

FONTE: COLEÇÃO MARC LE COEUR.

44 Sejam 12 estabelecimentos sobre 77: Bar-le-Duc, Châteauroux, Coutances, Douai, Evreux, Grenoble, Lyon, Le Mans, Napoléon-Vendée (La Roche-sur-Yon), La Rochelle, Saint-Quentin e Vesoul. Dos cinco primeiros liceus parisienses, um conseguirá se livrar totalmente: Louis-le-Grand, na véspera de sua reconstrução, em 1884. 
até a I Guerra Mundial. Em Paris, em especial, os grandes liceus de meninos Janson, Montaigne, Buffon, Voltaire e o novo Louis-le-Grand são orgulhosamente consagrados como imponentes monumentos urbanos, cujas fachadas formavam muralhas que, de todos os lados, preservavam os espaços de recreação de todo o contato externo.

Associado por vezes a abertura de novas vias, ${ }^{45}$ os novos liceus contribuiriam, doravante, para o embelezamento, mas também ao crescimento de seus respectivos bairros, levando consigo um grande número de famílias burguesas. ${ }^{46}$ Diferente de seus antecessores, eles concorrem ao dinamismo da cidade. Um mês antes do funcionamento do liceu Janson-deSailly, em 23 de agosto de 1884, o jornal Le Temps observou que se "podia, sem exagero, contar duzentos e cinqüenta a trezentas novas residências em um raio de quatrocentos metros em volta do liceu," fenômeno que se reproduziu alguns anos mais tarde nos locais do liceu Buffon como naqueles do liceu Lakanal. ${ }^{47}$ Como escreveu Gustave Dupont-Ferrier a propósito do Buffon e do Janson, "o bairro feito tanto para a fortuna do liceu, como o liceu para a fortuna do bairro." 48

Curiosamente, os liceus para meninas não obedeceram às mesmas regras, pois a raridade e o custo elevado dos terrenos no centro de Paris

45 O liceu Montaigne ocupou uma parte do antigo canteiro do Jardim de Luxembourg, cujo loteamento foi feito no final do Segundo Império; o liceu Voltaire aproveitou-se do prolongamento da Avenida da République e o primeiro local destinado para o liceu Buffon deveria permitir aquele da Avenida Duquesne até o Boulevard dos Invalides. Quanto ao liceu Louis-le-Grand, sua reconstrução permitiu o alargamento das Ruas Saint-Jacques (a leste) e Cujas (ao sul). Em certos casos, a abertura de uma rua não tinha outra finalidade senão afastar as habitações do novo liceu: assim a Rua de Staël (atrás do liceu Buffon) e a Rua Spinoza (sobre o lado direito do liceu Voltaire) foram, em sua origem, simples vias de isolamento abertas à circulação.

46 "Por volta de 1875, os pais ainda hesitavam em fixar residência nos bairros de onde seus filhos se deslocavam para se instruir em estabelecimentos do Estado" (DUPONTFERRIER, G. Les Écoles, lycées, collèges, bibliothèques. L'enseignement public à Paris. Paris: Laurens, 1913. p. 199).

47 Em 4 de abril de 1892, um rumor insidioso pretendia expulsar o liceu Lakanal para dar lugar à Escola Politécnica. Seu diretor escreveu a seguinte carta ao vice-reitor Gréard: "Os professores do liceu que têm uma classe todos os dias alugam apartamentos em Bourg-la-Reine ou em Sceaux e movimentam assim os negócios dos proprietários, assim como seus diversos fornecedores; alguns têm pensionatos em suas casas. Há famílias já instaladas na vizinhança do liceu que não habitariam ali se o liceu fosse suprimido, pois eles vêm a Bourg-la-Reine ou a Sceaux unicamente para colocar seus filhos em nosso liceu".

48 DUPONT-FERRIER, 1913, op. cit., p. 207. 
privavam a administração de vastas ilhotas, assim como o governo desejava fazer dos estabelecimentos construções mais modestas e de caráter familiar. Exceto o liceu Molière - o mais "masculino" dentre eles -, os liceus de meninas aparentavam amplas residências burguesas, encaixadas entre imóveis e abertas sobre vias secundárias, ao abrigo do tumulto da cidade. Nestes casos, somente constata-se que os arquitetos não apresentaram condições muito favoráveis: os liceus Fénelon e Lamartine são fundados em edifícios de antigos hotéis particulares, dos quais uma parte mais ou menos importante foi conservada in fine; o liceu Racine, que sucede a uma antiga e sombria construção, foi construído sobre uma área muito estreita e pouco favorável, em contra-altura da Rua do Rocher; quanto ao liceu Victor-Hugo, localizado na passagem entre as dependências do Museu Carnavalet e a antiga Biblioteca Histórica da Cidade de Paris (Hotel Lepeletier de Saint-Fargeau), teve que incluir um passadiço no primeiro andar para religar estas duas instituições municipais.

\section{Aumentar}

Que eles tenham sido construídos ou não para um uso escolar, que eles fossem fechados ou perfeitamente isolados, todos os estabelecimentos deviam seguir os progressos da higiene, adaptar-se pouco a pouco a especialização dos espaços de ensino e fazer face ao constante aumento de sua população que se impôs freqüentes desdobramentos de classes. A exemplo dos edifícios hospitalares, estes edifícios estavam condenados a constantes ajustes.

De maneira recorrente, os liceus procuravam esconder a carência de locais. Vários modos de extensão que podiam variar segundo a época e as disposições individuais se ofereciam a eles, o que nos leva, portanto, estudar caso a caso. Muitas vezes, a extensão ou a configuração de seus terrenos não edificados - jardins ou espaços de recreios - permitiu novas construções dentro dos limites da área (Condorcet, Henri IV, Michelet, Lamartine, Carnot, Jules-Ferry); quando isto não foi possível, pôde-se excepcionalmente, considerar a aquisição de propriedades contíguas (Racine, Buffon) ou o aumento dos edifícios existentes, com o risco de sobrecarregá-los e de agravar os espaços de recreios (Condorcet...). 
Em certas épocas, todavia, os liceus estiveram impossibilitados de se expandir por mais tempo. Foi assim no início de 1880, simultaneamente com a convergência de um número considerável de alunos e a aplicação do novo plano de estudos de ensino secundário. O liceu Louis-le-Grand e o Saint-Louis foram forçados a construir com urgência conjuntos de construções provisórias no meio dos espaços de recreios, e o liceu Condorcet, cujos locais estavam mais que saturados, teve que alugar uma série de lojas na Rua de Rome para abrigar sua divisão elementar e requisitar a sala do chefe de disciplina escolar e do diretor para ali fazer uma classe! $\mathrm{Na}$ incapacidade de responder de maneira satisfatória a estas necessidades imperiosas, a administração vai encorajar a criação de anexos: os pequenos liceus.

\section{Os pequenos liceus}

Há muito tempo, a administração se preocupava particularmente com as crianças, porque elas demandavam cuidados próprios à sua idade e delas dependeria o aumento numérico e a qualidade da população dos estabelecimentos nas classes superiores. O recrutamento dos liceus já se fazia pela base. Também os edifícios deveriam, ao menos em teoria, ser arrumados de maneira a impedir qualquer comunicação entre os alunos de idades diferentes, para evitar que os mais velhos pervertessem seus colegas mais novos por suas maneiras maldosas. ${ }^{49}$ Assim como os médios e os grandes, os pequenos liceus deveriam dispor de seu próprio bairro, com espaços de recreios, dormitórios, salas de aula e estudos, e, quando as dimensões da área o permitiam, um edifício especial, separado das outras construções, deveria lhes ser atribuído. ${ }^{50}$

49 Cf. THIERCÉ, A. Révoltes de lycées, révoltes d'adolescents au XIXe siècle. Histoire de l'éducation, n. 89, p. 59-93, jan. 2001.

50 A divisão do estabelecimento em vários "bairros" foi conforme o que se praticava na mesma época nos hospitais e prisões. Em 1868, 13 liceus dos departamentos e um único liceu parisiense tiveram pequenos liceus totalmente isolados do restante do estabelecimento: Amiens, Angers, Bourges, Douai, Laval, Limoges, Metz, Moulins, Nancy, Orléans, Rouen, Tours, Versailles e Henri IV (desde 1857). 
Os pequenos liceus, construídos sob a III República (1870-1940), diferem de seus antecessores pois, levados para um novo local, eles não tinham somente o objetivo de manter a uma certa distância as crianças menores; eles deveriam primeiramente reduzir o acúmulo dos velhos liceus (pequeno liceu Condorcet, 1882; pequeno liceu Louis-le-Grand, 1885) e, em alguns casos, procurar àqueles que possuíam cursos de recreação, ginásio coberto ou o externato controlado, que faziam falta (pequeno liceu Charlemagne, 1877; anexo do liceu Fénelon, 1912). A criação de tais anexos foi evidentemente problemática.

A aquisição de um terreno que estava separado do estabelecimento principal somente por uma rua calma e pouco freqüentada (o que tornou inofensivas as múltiplas idas e vindas) pareceu ser uma solução aceitável, experimentada em outras épocas ou em outros lugares, ${ }^{51}$ adotada pelo liceu Charlemagne e pelo liceu Fénelon mais estranhamente julgada "inadmissível" pelo liceu

FIGURA 3 - LICEU MONTAIGNE

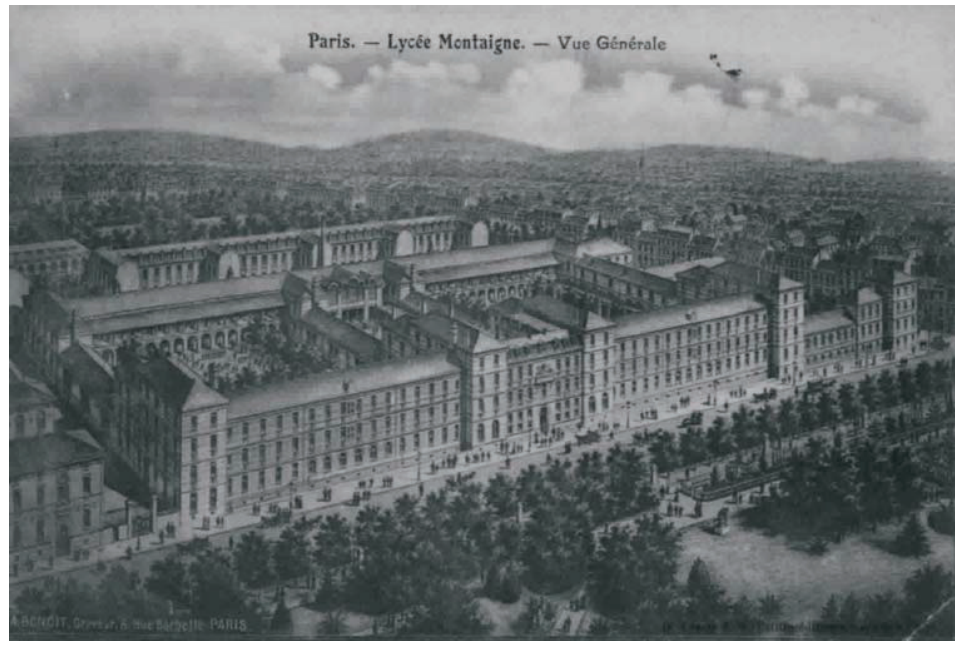

FONTE: COLEÇÃO MARC LE COEUR.

51 Durante vários séculos, o Colégio de Harcourt se prolongava de uma parte e de outra da Rua da Harpe e, sob o Segundo Império, três liceus dos departamentos foram igualmente separados em dois por uma rua (em Bordeaux, Lyon e Napoléon-Vendée). Na maioria dos casos, uma passagem subterrânea e/ou uma galeria na altura do primeiro andar permitia a comunicação entre os dois edifícios. 
Buffon - no qual faltava, desde 1889, um terceiro curso de recreação -, esta disposição permitiu um simples complemento das instituições existentes. Isto ocorreu diferentemente para os pequenos liceus Condorcet e o Louis-le-Grand, pois alguns metros os separam de suas respectivas casas-mães

Em razão da penúria dos terrenos alienáveis a seus acessos imediatos, a administração foi obrigada a duplicar literalmente os grandes liceus; desde que, seus anexos beneficiassem - em mais salas de aula e de estudos, e eventualmente dormitórios - de seus próprios locais administrativos, de um parlatório, cozinhas e refeitórios, um ginásio coberto e, no caso eventual, de uma capela, em suma de todos os espaços que compõem o liceu autônomo. Também estes estabelecimentos tinham de pequeno somente a denominação: o pequeno liceu Condorcet é mais espaçoso que os futuros liceus Racine e Victor-Hugo, e o pequeno liceu Louis-le-Grand é apenas menor que o grande liceu da Rua Saint- Jacques!

Nada de surpresa, alguns dentre eles conquistaram rapidamente sua independência; em 1891, perto de 30 anos após ter perdido seu anexo de Vanves, o liceu Louis-le-Grand se desfez de seu pequeno liceu e, em 1893, o hotel particular do Faubourg-Poissonnière, onde o liceu Racine instalou as classes que lhe faltavam e, por conseguinte, liberou-se de sua tutela original. Os liceus Michelet, Montaigne e Lamartine inauguraram a proliferação dos estabelecimentos secundários (e em breve dos estabelecimentos universitários) por segmentação. ${ }^{52}$ Qualificado, desde 1863, o liceu Louisle-Grand de metrópole que funda colônias, M. Drouyn de Lhuys estava sem dúvida longe de imaginar que profetizava! $!^{53}$

\section{O bairro}

Encorajada pelas famílias, a administração foi responsável e ficou atenta ao que se passava nos arredores dos liceus e em seus contornos imediatos. Em primeiro lugar, ela se dedicava em manter à distância os estabelecimen-

52 Este modo de reprodução se espalhou particularmente após a Segunda Guerra Mundial. Assim, o liceu Rodin foi fundado em 1960, na XIII Circunscrição Administrativa, mas teria sido construído quatro anos antes, como anexo do liceu Montaigne.

53 Bulletin administratif du ministère de l'Instruction publique, 1864 (II). p. 81. 
tos insalubres, perigosos ou barulhentos. Se a construção dos reservatórios municipais, cercando um dos espaços de recreio do liceu Saint-Louis e um mercado coberto atrás do pequeno liceu Charlemagne, não puderam ser evitados, por pouco que o liceu Michelet não se avizinhou com uma fábrica de sabão, uma usina de depuração para vela ou um cemitério, e que o liceu Buffon não sofreu com a proximidade de um ateliê de debulha de grandes tapetes e o liceu Montaigne, de uma parede meia com a Associação dos estudantes, cujo potencial subversivo arriscava contaminar a população pré-adolescente do estabelecimento.

A atenção da administração se exercia tanto sobre o comércio, como também com a venda de bebidas nas proximidades. Sob o II Império, vários cafés de Paris, assim como uma butique de frutas e doces da Rua de Vaugirard foram colocadas sob vigilância do prefeito de polícia, pois se viu entrar nestes locais alunos uniformizados dos liceus. Na mesma época, a passagem do Havre, com uma reputação de local de depravação, pois os alunos do liceu Condorcet se reuniam neste local antes de entrar em classe e podiam ali procurar guloseimas, imagens licenciosas, romances libertinos ou panfletos políticos. ${ }^{54}$

Mas a moral das crianças não foi a única preocupação da administração, que se inquietou igualmente com os professores e sobretudo com os mestres de estudos que residiam nos liceus e freqüentemente eram tentados a procurar distrações fora, em locais onde eles comprometiam a dignidade de suas funções. Também, por falta de poder regulamentar seus momentos de lazer, procurou-se desvia-los dos cafés e dos cabarets, oferecendo-lhes dentro dos estabelecimentos, espaços de estudo, verdadeiros locais de sociabilidade, que buscavam melhorar suas condições de trabalho, permitindo exercer sobre eles uma vigilância tanto eficaz quanto dissimulada: a partir de 1838, uma sala de leitura, convenientemente mobiliada

54 Fora dos estabelecimentos, estando por vezes livres, os externos podiam se reencontrar nos recantos ocultos da cidade próximos aos liceus, escapando assim da vigilância dos adultos. Os alunos do pequeno liceu Condorcet estabelecem seu próprio quartel general na cité Monthiers: "É o seu local de greve, uma espécie de praça da Idade Média, de corte de amor, dos jogos, dos milagres, de local de contrabando de selos e bolas de gude, de recanto oculto onde o tribunal julga os culpados e os executa, onde se conspiram estas brincadeiras que chegam em classe cujos preparativos espantam os professores" (COCTEAU, J. Les Enfants terribles. 1929. Paris: B. Grasset, 1985. Reedição, p. 15-16). 
e aquecida para as alocações do colégio e aberta das $10 \mathrm{~h}$ às $22 \mathrm{~h}$. Posteriormente foram utilizadas como sala de reuniões, jogos e salão de leitura. Tais salas aparecem nos liceus parisienses, primeiro no Henri IV (1865), depois no Michelet (1869), Janson (antes de 1892) e no Voltaire (1893).

A via pública

Divididos entre o desejo de ser afastado do tumulto da cidade e a necessidade de se ter um acesso fácil, os estabelecimentos mantiveram relações equívocas com a via pública. Nos primeiros tempos, o estreitamento das ruas que os circundavam podia entravar o estacionamento dos carros nas horas em que circulavam os alunos $;{ }^{55}$ foi o caso da Rua dos Postes

\section{FIGURA 4 - LICEU SAINT-LOUIS}

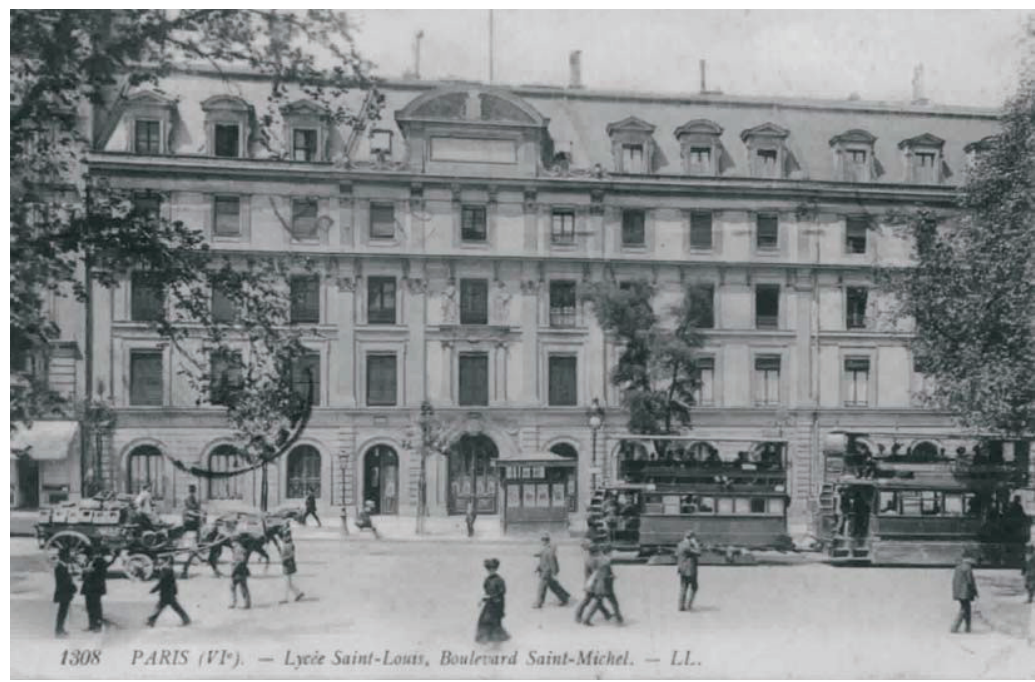

FONTE: COLEÇÃO MARC LE COEUR.

55 Segundo Vallés, o colégio Real do Le Puy "se deu como todos os colégios, como todas as prisões, em uma rua obscura" (VALLÉS, J. L'Enfant, 1879. Paris: Le Livre de Poche, 1985. Reedição, p. 39). 
(Lhomond) ou Rua Saint-Jacques em frente aos antigos colégio Rollin e liceu Louis-le-Grand. ${ }^{56}$ Mais tarde, alguns dentre eles foram incomodados pela agitação dos Boulevards Saint-Michel (Saint-Louis) e Pasteur (Buffon).

$\mathrm{O}$ barulho e as trepidações ocasionadas pela circulação eram nocivos, quando se procurava uma calma propícia ao estudo, no qual se podia conduzir experiências científicas.

Embora todos os arquitetos não pressentissem o incômodo real que poderiam experimentar professores e alunos, porque eles não examinaram suficientemente os acessos dos estabelecimentos - tarefa pela qual estavam encarregados -, acabando por adotar distribuições prejudiciais à vida escolar.

Nos anos de 1880, resgata-se o recurso de galerias cobertas sobrepostas, cuja implantação sobre o contorno dos espaços de recreio impôs a necessidade de abrir salas de estudos ao longo da via pública, ao contrário do que se praticava nas escolas primárias. Este agenciamento, que resultou notadamente da conjunção de determinações higienistas (dar uma dupla ventilação a todas as peças, como nos edifícios hospitalares) e constrangimentos disciplinares

\section{FIGURA 5 - LICEU LOUIS-LE-GRAND}

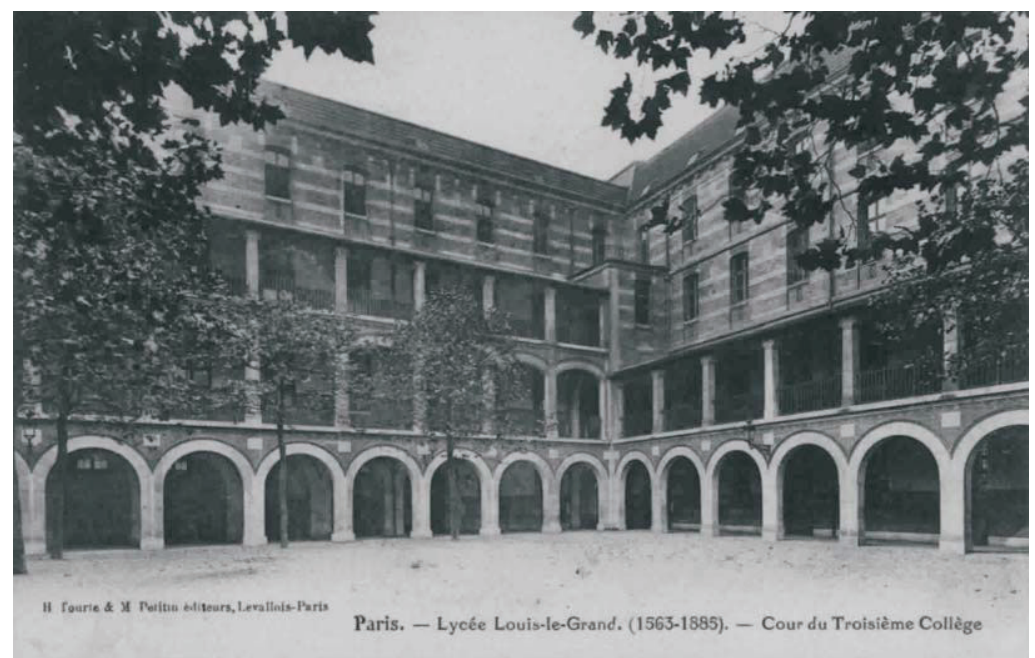

FONTE: COLEÇÃO MARC LE COEUR.

56 Em 1839, a municipalidade consente enfim em abrir uma praça em frente ao liceu Louis-le-Grand, ao fim da Rua Gerson. Cinqüenta anos mais tarde, o desaparecimento da Praça Gerson (absorvida pelos edifícios da nova Sorbonne) será compensado pelo alargamento da Rua Saint-Jacques. 
(poder cuidar de um mesmo ponto de todos os movimentos dos indivíduos, como na arquitetura carcerária) foram muito requisitadas pelos arquitetos escolares, ao ponto de se tornar uma especificidade dos liceus e colégios julesferriens. Em Paris, o novo liceu Louis-le-Grand, o pequeno Condorcet, e os liceus Janson, Lakanal, Montaigne, Molière e Buffon deram magníficos e, por vezes, espetaculares exemplos de desenvolvimento.

Esta parte do claustro decorativo (como o chamava pejorativamente um de seus detratores) foi condenada por certos arquitetos que o criticavam como inadequada ao clima parisiense, que expunha os alunos ao frio, ao vento e às chuvas oblíquas quando saíam da classe; por outro lado, a lateralidade da sala junto à rua prejudicava a serenidade dos estudos. Esta última reprovação justificada. Em alguns casos, a passagem de carros abaixo das salas de aula ocultava a voz dos professores e impedia que se abrissem as janelas em dias de sol, durante a lição.

\section{FIGURA 6 - LICEU BUFFON}

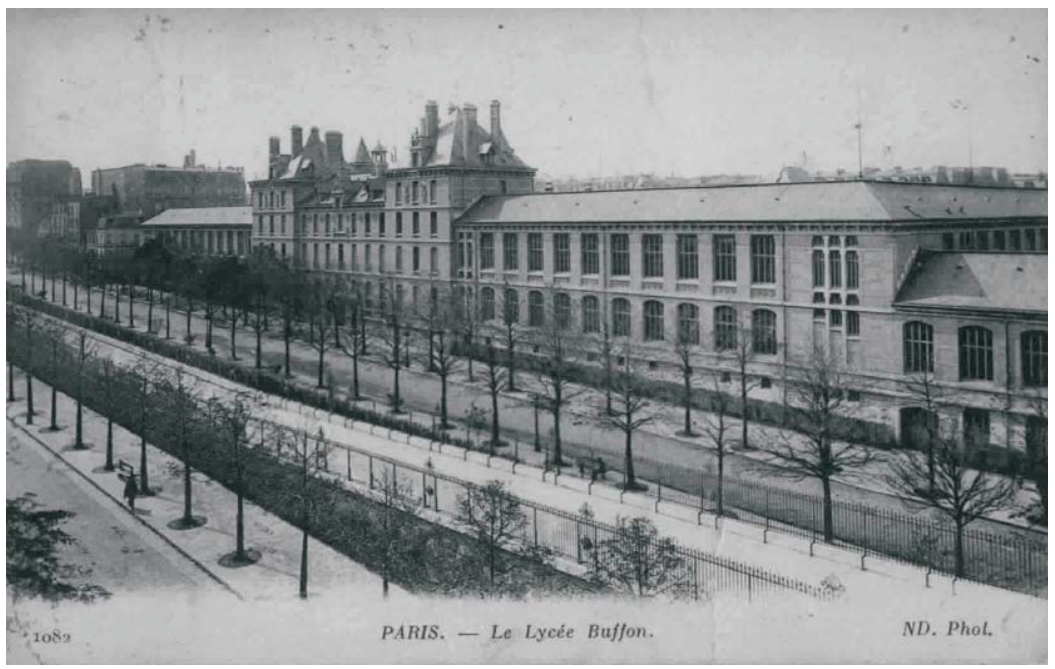

FONTE: COLEÇÃO MARC LE COEUR.

Desse ponto de vista, o liceu Buffon foi sem dúvida o mais importunado de todos os liceus de Paris, pois seu arquiteto colocou vinte novas salas de aula e de estudos margeando as vias mais movimentadas que eram 
o Boulevard Pasteur e a Rua de Vaugirard $!^{57}$ À véspera de sua abertura, antecipando as reclamações dos professores, o diretor conseguiu a substituição do pavimento da rua, que era de pedra, por um de madeira ou de macadame. Contudo, este melhoramento realizado antes dos demais estabelecimentos parisienses não ensurdeceu o alarido da circulação provocado pelo funcionamento provisório, em 1906, de uma linha do metrô de superfície, sobre o terreno central do Boulevard Pasteur, o que arruinou definitivamente todas as esperanças de tranqüilidade. ${ }^{58}$

Um outro inconveniente participou deste dispositivo. Ainda que os alunos estivessem em aula, podiam se distrair pela animação das ruas e pela curiosidade dos transeuntes. Assim, as regulamentações recomendavam não localizar as salas de aulas e estudos no térreo. Se não havia outro modo, os edifícios deveriam ser construídos recuados do alinhamento e precedidos de uma grade da qual se poderia plantar flores ou arbustos.

\section{Fugir da cidade: o sonho dos liceus no campo}

O projeto de transferir os liceus, ou ao menos uma parte dentre eles, para a periferia das cidades foi resultado de um longo processo, cuja origem foi diretamente ligada à mediocridade das condições de instalação primitivas dos estabelecimentos. Já em 1776, o governo havia intencionalmente fundado, no campo, uma rede de doze pensionatos (as escolas reais militares), decisão inovadora, mas que se reservava somente a algumas centenas de alunos o benefício da vida ao ar livre. Volta a aparecer no II Império e depois na III República a tentativa de generalizar esta fórmula, de

57 Construído no mesmo tempo, o liceu Voltaire adotou o partido inverso: desviando da rua todos os espaços escolares. Um simples corredor circundava o edifício, à exceção do edifício principal na Avenida da Republique, onde o arquiteto colocou apenas quatro salas de classe e dois anfiteatros.

58 "Ele nos lembra do suplício dos professores obrigados a lutar em alta voz com o trovão do metropolitano que avança fora da terra em frente ao liceu, para lançar aos quatro ventos do céu seu barulho de ferragem. É verdade que os trens passam de três em três minutos, mas como os trens se cruzam, tem-se por vezes um minuto e meio tranqüilidade" (DUPONTFERRIER, 1913, p. 208-209). 
erigi-la como um sistema. Influenciado pelas maneiras inglesas, este plano tomou igualmente seu recurso em uma reflexão mais geral sobre os locais que convinham daquele momento instituir extra muros a certos estabelecimentos comunitários. Em Paris, em particular, inúmeros problemas foram apresentados para a sua inserção na cidade, a densificação do tecido urbano, a rarefação e a carestia dos grandes terrenos para construção.

Inúmeras vozes se elevaram para reclamar o distanciamento em direção aos arredores da cidade para as populações mais frágeis fisicamente e moralmente, as mais improdutivas também: os velhos, os doentes, os convalescentes... e os alunos dos liceus.

\section{Um motivo para passear}

Em todo tempo, os colégios procuraram fora dos muros da cidade a natureza que eles não podiam encontrar nas suas proximidades. Propriedade da Universidade de Paris, o Pré-aux-Clercs foi assim durante muitos séculos, o objetivo de passeio comum a todos os bolsistas e pensionistas da capital, mas a freqüência e a gravidade dos incidentes que ali se produziam regularmente, terminaram por conduzir a perda desta longa faixa de terra que se estendia ao longo do rio Sena, adiante da Pont-Neuf.

Em dias de feriado, os passeios se faziam em diferentes pontos da cidade, em grupos dispersos com o risco de submeter as crianças a encontros indesejáveis com livros perigosos e imagens obscenas apresentadas nas vitrines das butiques, as tentações dos comerciantes ou ao ar viciado das ruas parisienses. ${ }^{59} \mathrm{Em} \mathrm{1767}$, desejando fazer cessar as desordens causadas pelos alunos dos colegiais, o governo considerou a compra de um vasto terreno onde todos poderiam estar de novo reunidos, em Montparnasse, nos arredores do Saint-Marcel ou atrás da Salpetrière, mas a lembrança dos confrontos do Pré-aux-Clercs causou o abandono do projeto. ${ }^{60}$ Os estabelecimentos de-

59 ÉMOND, G. Histoire du collége de Louis-le-Grand depuis sa fondation jusqu'en 1830. Paris: Durand et Loisel, 1845. p. 261; BOUQUET, op. cit., p. 410.

60 BOUQUET, op. cit., p. 410-412. 
veriam então se arranjar sozinhos, a exemplo do colégio Louis-le-Grand que há muito tempo dispunha de sua própria casa de campo, em Issy (c.15851595) depois em Gentilly (1631-1764) ou a Comunidade de Sainte-Barbe, cujo domínio, igualmente em Gentilly, foi conquistado por volta de 1740.

\section{Os anexos campestres}

Em 1787, enquanto ninguém havia pensado ainda em fazer uma jornada com os alunos no campo por mais de um dia, a comunidade de SainteBarbe decidiu transferir permanentemente para esta localidade as pequenas classes que não podia abrigar em seus locais do Quartier Latin. ${ }^{61}$ A separação de um mesmo estabelecimento em dois locais distintos, afastados por alguns quilômetros, e a criação de um grupo de noviciado campestre constituiram uma experiência inédita, à qual a Revolução põe fim quatro anos mais tarde. Mas a idéia faz seu caminho: sob a Restauração, um chefe de instituição, M. Morin, e um mestre de pensão, M. Savary, fundam anexos respectivamente em Fontenay e em Passy.

Não se trata mais, desta vez, de responder a muitas necessidades pragmáticas, mas em melhor considerar a questão sob o ângulo pedagógico ou profilático. ${ }^{62}$ Mesmo que efêmeras e isoladas, estas ações testificaram a propagação dos preceitos higienistas, ${ }^{63}$ que demonstravam uma desconfi-

61 QUICHERAT, J. Histoire de Sainte-Barbe. Collège, communauté, institution. Paris: Hachette, 1862. t. 2, p. 377-378.

62 QUICHERAT, J. Histoire de Sainte-Barbe. Collège, communauté, institution. Paris: Hachette, 1864. t. 3, p. 321.

63 Em 1838, um médico e um professor bordelês escrevem que a necessidade de colocar harmonia à educação física e intelectual da infância é profundamente sentida desde muito tempo. Após lamentarem que os planos estudados até então fracassaram na prática, eles recomendaram a criação, "primeiro em Paris, em seguida nas localidades favoráveis para cada academia, de um estabelecimento especial no qual os cuidados intelectuais seriam completamente subordinados aos cuidados higiênicos, dietéticos e médicos, e isso ao contrário do que existe em todos os colégios" (POUGET; VALAT. Plan d'organisation hygiénique et médicale pour les collèges royaux. Bordeaux: [s. n.], 1838. p. 3-21). A ginástica escolar fez sua aparição um pouco cedo sob o impulso do coronel Amoros, primeiro na instituição Durdan (1818), depois nos liceus de internos de Paris: no Liceu Louis-leGrand, em 1829, no Henri IV, em 1831, e no Saint-Louis, em 1836. 
ança crescente em relação à vida na cidade. E dali em diante, foi admitido que o espaço e o ar puro eram indispensáveis às crianças, que as retirando do torpor das fadigas do claustro, ${ }^{64}$ do tumulto da cidade, com suas ruas obstruídas e suas indústrias, as fortaleciam, favoreciam suas crenças e preveniam suas doenças.

Desde 1840, M. Pierrot foi o primeiro reitor (de liceu) a propor o distanciamento de seu pequeno colégio até uma propriedade que possuía o liceu Louis-le-Grand em Vanves ${ }^{65}$ Mesmo com a aprovação do ministro Villemain, o projeto não foi realizado imediatamente, mas nos edifícios de Plessis, cujo estabelecimento instalou crianças de 9 anos em diante. Freqüentemente, sobre este ponto somado a outros, as iniciativas privadas anteciparam a ação da administração e, em alguns anos se esgotaram, antes que jovens dos liceus fossem autorizados a gozar de maneira permanente dos benefícios do campo: em 28 de junho de 1853, um ano após que o colégio Sainte-Barbe inaugurasse sua nova sucursal (Sainte-Barbe-desChamps), na antiga propriedade da instituição Morin em Fontenay, uma decisão ministerial decidiu transferir a divisão elementar do liceu Louis-leGrand para Vanves. As famílias aprovaram esta melhoria. Como poderia ser de outro modo? Em Vanves tudo comprovava que um pequeno colégio podia ser um jardim, mas não caserna ou prisão.

Com o grande sucesso desta importante reforma, o ministério da Instrução Pública a recomenda, oito anos mais tarde, a todos os estabelecimentos do país: "nas grandes cidades, onde o ar e o espaço são raros, é de se desejar que o pequeno colégio forme uma sucursal completamente distante e localizada no campo." ${ }^{66}$ Assim, depois dos liceus de Bordeaux (1859) e de Montpellier (1860), os estabelecimentos de Marseille (1863) e de Lyon (1864) abriram seus anexos campestres. ${ }^{67}$ Enfim, para estender suas vantagens a um maior número de alunos, o governo declarou a maison de Vanves comum a três liceus de internos da capital (1863) antes de pronunciar sua emancipação e de

64 BAUDELAIRE, C. Épître à Sainte-Beuve. 1843.

65 Trata-se da antiga propriedade dos duques de Condé. Adquirida pelo atual liceu Louis-le-Grand desde 1798, o domínio seria transformado, em 1836, à custa de algumas mudanças, na residência de verão dos pensionistas que não passavam as férias com os pais.

66 Lycées impériaux. Programme pour les bâtiments. 1861. Projet.

67 Na mesma época, os liceus de Nantes, Nîmes, Orléans, Poitiers e Reims possuem igualmente propriedades no campo, mas sem um verdadeiro anexo.

68 Statistique de l'enseignement secondaire en 1865. Paris: Imprimerie impériale, 1868. p. 127. 
fazer o $6^{\circ}$ liceu parisiense, sob o patronato do pequeno Príncipe Imperial, com oito anos (6 de agosto e de 17 de setembro de 1864); o Ministro Victor Duruy pôde então elogiar com orgulho o estabelecimento "mais completo e melhor organizado, neste gênero, que existe na Europa." ${ }^{68}$ Naquela ocasião, na qual a edilidade multiplicava os jardins públicos no coração da capital e transferia vários hospícios e casas de repouso para os subúrbios, ${ }^{69}$ o movimento iniciado por duas vezes pelo Colégio Sainte-Barbe conheceu seu apogeu.

\section{Externatos nas cidades/internatos no campo}

O entusiasmo para os liceus rurais não se enfraqueceu nos primeiros anos da III República. Ao contrário, vozes mais e mais numerosas reclamavam que este aperfeiçoamento, cessando de ser apanágio dos liceus os mais jovens, fosse dali em diante aplicado a todas as faixas etárias e que o liceu de Vanves, em particular, fosse transformado em um estabelecimento em pleno exercício.

Os arquitetos subscreveram a estes ideais como em testemunho ao acolhimento favorável que encontram nas publicações profissionais dos projetos dos liceus no campo, que dois dentre eles - Lanck em 1873 e Degeorge em 1877 - estudaram por sua própria iniciativa. Mas, até 1880, os estabelecimentos de ensino privado investiram sozinhos nos subúrbios parisienses de Saint-Germain, Vincennes ou Fontenay-sous-Bois, Nogent ou Saint-Mandé, onde se encontravam ainda incomparáveis condições de salubridade e de tranquïlidade, assim como vastas propriedades cujo o preço para a compra era muito menor em comparação ao custo dos terrenos no centro de Paris. ${ }^{70}$

Enfim, a administração de Jules Ferry decidiu satisfazer a opinião pública; assim fazendo, ela esperava também por fim à crise que então atravessava o internato. Em sua memória sobre L'Enseignement secondaire à Paris en

69 Após dois asilos imperiais, foram fundados em Vincennes (1857) e em Vésinet (1859), a instituição Sainte-Périne e o hospício dos Ménages mudam respectivamente para Auteuil (1862) e em Issy (1863), e os hospícios dos incuráveis homens e mulheres, reagrupados em Ivry (1868).

70 Em 1881, o preço do metro quadrado em Sceaux era de 2,60 francos (liceu Lakanal: 255.000 francos para $98.268 \mathrm{~m} 2$ ) ainda que em Paris, ao norte da estação SaintLazare, o metro quadrado custava 486,30 francos, ou seja, 187 vezes mais caro (pequeno liceu Condorcet: 1.400.000 francos para 2.878,85 $\mathrm{m}^{2}$ ). 
1880 (O Ensino Secundário em Paris em 1880), o vice-reitor Gréard reconhece voluntariamente, após vários autores, que o aquartelamento dos alunos poderia ser vicioso, tanto no ponto de vista dos costumes como de higiene ou de educação. Mas o regime de internato, se não constitui "a melhor das instituições" foi ao menos uma "instituição indispensável" que, em razão de sua prática secular, não seria modificada em um dia. ${ }^{71}$ Também, tomando por modelo os colégios ingleses, propunha transferir todos os futuros liceus de internos para o campo: "Nós teremos feito um passo considerável, quase decisivo, no dia em que for criado mais internatos fora das cidades. (...) Em Paris mesmo, é o externato somente que procura se desenvolver."'72

A partir de 1881, os regulamentos oficiais sobre a instalação dos liceus e colégios ratificaram a proposição de Octave Gréard. ${ }^{73}$ Embora, após alguns anos, um certo Maneuvrier denuncia "a inércia dos poderes públicos," que ele acusava, com uma má fé manifesta, de não ter ainda nenhum projeto para curar "esta velha enfermidade nacional" que são os internatos escolares e de permanecer surdos à "cruzada dos médicos e dos moralistas contra os liceus da cidade!" Os fatos parecem lhe dar razão: "Construí-se ou se reconstruí na província, desde 1870, mais de quarenta liceus ou colégios. Somente no exercício de 1886-1887, inaugurou-se onze. Quantos vocês acreditam que se construiu no campo? Nem um só!"74 A constatação foi fundamentada, mas o governo não seria acusado de carência. Não se levantou a especificidade infantil do atual liceu Michelet (1881) e fez-se construir o liceu Lakanal (1885), que os contemporâneos consideravam

71 GRÉARD, O. L'Enseignement secondaire à Paris en 1880. Paris: Delalain, 1880. p. $15-16$.

72 Ibid., p. 16-17. Nos anos seguintes, a administração criou três liceus para os externos em Paris: Buffon e Voltaire, depois Carnot. Somente os dois liceus em pensionato (Janson e o pequeno Louis-le-Grand, atual liceu Montaigne) gozavam da vizinhança próxima de dois grandes espaços verdes: o Bois de Boulogne e o Jardim de Luxembourg. Quanto aos liceus de meninas, estes foram todos externatos, à exceção do liceu Victor-Duruy, onde um verdadeiro parque foi substituído pelo tradicional espaço de recreio.

73 "Em alguns centros importantes, notadamente em Paris, pode-se instalar no interior das cidades dos liceus recebendo meio pensionista e externos (...), e, no campo, liceus destinados unicamente aos pensionistas e aos meio-pensionistas" (Nota relativa às condições de instalação dos liceus e colégios, 1881). Do mesmo modo, a partir de 1881, o governo fundou vários estabelecimentos de formação de professores do primário e do secundário no subúrbio sul de Paris: em Sèvres, Saint-Cloud, Fontenay-aux-Roses e Sceaux.

74 MANEUVRIER, E. L'Éducation de la bourgeoisie sous la République. Paris: Léopold Cerf, 1888. p. 264. 
FIGURA 7 - LICEU LAKANAL

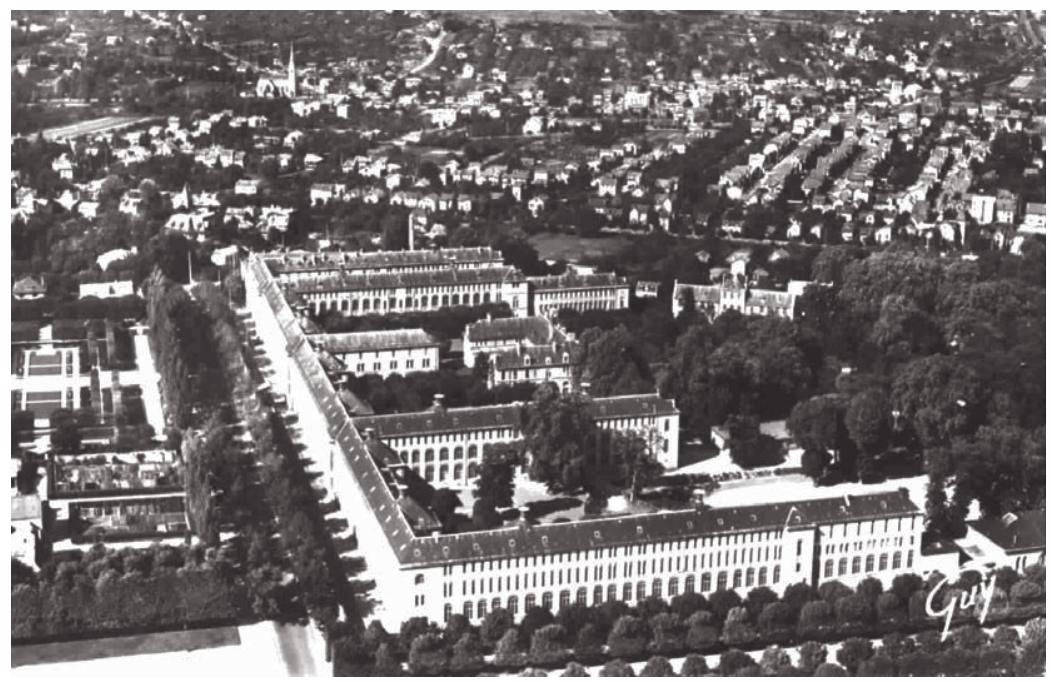

FONTE: COLEÇÃO MARC LE COEUR.

um justo título como o mais moderno, o mais arborizado, o mais inglês também dos liceus franceses? O balanço foi contudo sustentado e bem longe dos objetivos da administração. ${ }^{75}$

Por que uma medida tão salutar não teve o sucesso que era de se esperar? a obstinação das cidades da província de fundar liceus ou colégios nos bairros mais populosos se explicava pelo receio de não poder transferir para o campo um grande contingente de alunos, então, tal medida se fazia para assegurar a viabilidade do estabelecimento; quanto àquelas que já possuíam um liceu, as cidades receavam, sem dúvida, em criar um segundo na periferia, cuja construção certamente sobrecarregaria as finanças municipais e cuja utilidade no plano local não se fazia sentir. Mas o principal entrave residiu na crise do internato que não parecia acabar. Após tê-los reclamados, as famílias foram brutalmente direcionadas para os liceus rurais: construído para acolher 700 alunos em média, majoritariamente pensionistas, o luxuoso liceu Lakanal recebia menos de 400 alunos ao final do

75 Para a única academia de Paris, Gréard projetou a fundação de três internatos: em Drancy ou em Dugny (a nordeste), em Saint-Mandé (a sudeste) e nos confins de Neuilly (a oeste), que, com o Liceu de Vanves (ao sul), circulavam a cidade de Paris. 
século, antes de conseguir atingir penosamente o número de 672 alunos, dos quais 292 eram internos (43,4\%), à véspera da I Guerra Mundial; ao mesmo tempo, após uma afluência recorde em 1885 (1009 alunos), o liceu Michelet viu seu efetivo diminuir à metade passando a sua população de internos de $93,2 \%$ para $45,8 \% \ldots$ Os dois estabelecimentos deveriam servir de modelo para os novos liceus, posto que ficaram como experiências excepcionais sem futuro: o sonho dos internatos no campo era recente, vítima das dificuldades de sua realização e da mudança de mentalidades.

\section{A pacificação}

A secularização do corpo docente e o declínio dos internatos escolares exerceram uma influência decisiva sobre o processo de reconciliação dos liceus com seu meio. Pois, não desagradavam alguns contemporâneos. ${ }^{76}$ Os liceus da III República diferiam de seus antecessores napoleônicos, os quais mantém algo da caserna e do convento; por muito tempo lugar de estadia permanente, eles foram transformados em lugares de passagem para um número crescente de professores e de crianças que não os freqüentavam mais que por um espaço de algumas horas quotidianas. Incapaz de refrear esta irresistível evolução - como em testemunho do fracasso dos liceus no campo - a administração devia se resignar a suportar os efeitos e emendar os artigos de regulamentação interior dos estabelecimentos que se tornaram obsoletos.

Eis que é enfim elevada a interdição feita aos alunos de conversar durante as refeições, e também a presença de professor de sexo feminino, encarregado então das pequenas classes...

A opinião pública o impunha: os liceus não deveriam mais ser universos marginais, isolados do mundo, onde as crianças eram instruídas em toda ignorância das realidades da vida civil.

76 Jules Vallès, um dos mais virulentos adversários dos liceus, conta, em 1882, que "as crianças ficam reféns dos padres ou dos soldados nos corredores destes pequenos cubículos, onde elas têm sido encerradas sob o protesto dos pais (...) ou sob um julgamento dos magistrados que as teriam achado criminais" (VALLÈS, J. Les lycées. La France, out. 1882). 
Outros indícios traíram esta lenta mutação da instituição escolar: sob o impulso dos Ministros Victor Duruy e depois Jules Simon, a cidade e o campo tornaram-se verdadeiros suportes pedagógicos, campos de investigação onde os alunos eram convidados a explorar com a condução de seus professores; ${ }^{77}$ simultaneamente, os estabelecimentos empreenderam abrir ocasionalmente uma parte de seus locais a um público novo: no princípio da guerra de 1870, o ministro Mège autoriza a ocupação dos edifícios escolares por grupos e ambulâncias militares, argumentando que "os deveres do patriotismo dominam a todos." ${ }^{\text {78 }}$ Nos primeiros meses da III República, certas escolas comunais são autorizadas a dispor dos ginásios cobertos dos liceus para cerimônias de distribuição de prêmios; no verão de 1899, a sala de festas do liceu de Rennes abrigou o segundo processo do capitão Dreyfus, acontecimento extraordinário que não poderia ter acontecido em tal lugar alguns anos antes; à véspera da I Guerra Mundial, certos estabelecimentos de meninos acolheram reuniões eleitorais, cursos de adultos e mesmo cursos secundários para moças!

Após ter sido, por muito tempo, dominados pela cidade, os estabelecimentos parisienses pouco à pouco foram isentos: o reconhecimento de sua especificidade tem primeiramente cuidado com o isolamento - ao menos parcial - de seus edifícios, sua proliferação e uma melhor repartição sobre o terreno municipal; desobrigando-o por um lado de sua responsabilidade educativa, as famílias lhes tinham em seguida permitido de adotar uma atitude mais serena em atenção ao seu ambiente; enfim, a propagação das doutrinas positivistas, particularmente perceptível nos conteúdos de ensino, e o desejo reivindicado de fazer dos alunos dos liceus os futuros cidadãos, levaram a uma maior permeabilidade da instituição e dos edifícios.

No final do século XIX, a cidade não era mais um cinzel, mas uma verdadeira parceira com a qual os liceus não hesitaram mais a multiplicar as trocas, deixando de resistir ainda por muito tempo as coisas nocivas inerentes às grandes cidades: o barulho e a poluição.

77 Em novembro de 1864, Duruy exigia que os jovens parisienses visitassem, durante a baixa estação, os museus, as coleções científicas e as grandes usinas de Paris. Oito anos mais tarde, Jules Simon entende esta medida e institui aos alunos dos departamentos passeios topográficos nos campos, utilizando mapas do Estado Maior.

78 Bulletin administratif du ministère de l'Instruction. 1870, p. 390. Nas semanas que se seguiram, a sede de Paris obrigou os liceus parisienses a acolherem as companhias das guardas móveis e das guardas nacionais, até mesmo oficinas de equipamentos que, em certos casos, comprometeram o reinício das aulas em outubro de 1870. 
A história material do liceu Louis-le-Grand, o decano dos liceus parisienses e o mais prestigiado estabelecimento francês traduz sozinho este retorno. Após ter sofrido por muito tempo com as condições deploráveis de instalação e um contexto urbano prejudicial e escapado por pouco de uma transferência, após ter iniciado as sucursais campestres depois os pequenos liceus descentralizados antes de se fazer desapossar pouco a pouco de seus anexos, após ter penosamente conseguido se estender até as ruas circunvizinhas, o estabelecimento viu a administração satisfazer às suas reclamações à época de sua reconstrução (1885-1898): obtendo uma passagem pública seja aberta através da nova Sorbonne, em frente de sua entrada principal, que permitirá aos alunos do liceu de continuar a religar sem desvio o Boulevard Saint-Michel, antes de desfazer o conceito com os estabelecimentos universitários vizinhos, o projeto de abertura de uma linha de tramway com tração elétrica sobre a Rua Saint Jacques ${ }^{79}$ que é muito inclinada. Ao mesmo tempo, o arquiteto do liceu substitui cinco grandes aberturas envidraçadas por uma porta pesada de carvalho que, em tempo imemorial protegia hermeticamente o estabelecimento do exterior e cuja única vista fazia vibrar as crianças no retorno ao domić́lio familiar. Ninguém nota o quanto era insólita esta nova entrada. Embora ela fosse a expressão arquitetural e simbólica da busca de transparência de uma instituição que havia decidido romper definitivamente com a tradição de fecharse sobre si e da opacidade herdada dos colégios do Antigo Regime.

Texto recebido em 27 mar. 2003

Texto aprovado em 10 set. 2003

79 Aberta em $1^{\circ}$ de maio de 1901 e bem conhecida dos estudantes do Quartier latin, a Galeria Gerson não figurava nos primeiros planos de Henri-Paul Nénot, o arquiteto da nova Sorbonne. Sua criação tinha sido ardentemente reivindicada pelo reitor do liceu Gidel no início dos anos de 1890 e defendida pelo conselheiro municipal Deschamps, como a mudança da antiga rua que leva o mesmo nome e que a Sorbonne devia anexar. Quanto ao projeto do tramway, o mesmo foi estudado e depois abandonado em 1906. Ainda hoje, nenhuma linha de ônibus passa neste pequeno trajeto da Rua Saint-Jacques. 
ANEXO - LISTA DOS LICEUS PARISIENSES CRIADOS ANTES DE 1914*

\begin{tabular}{|c|c|c|c|c|c|}
\hline & $\begin{array}{c}\text { Nome atual do } \\
\text { estabelecimento }\end{array}$ & Clientela & Localização & $\begin{array}{c}\text { Em } \\
\text { funcionamento }\end{array}$ & $\begin{array}{c}\begin{array}{c}\text { Denominações sucessivas e natureza do } \\
\text { estabelecimento }\end{array} \\
\end{array}$ \\
\hline 1 & Louis-le-Grand & Meninos & $\begin{array}{c}\mathrm{V} \\
\text { Circunscrição } \\
\text { Administrativa }\end{array}$ & 1803 & \begin{tabular}{|l} 
Liceu de Paris (1803) \\
Liceu Imperial (1804) \\
Colégio Real Louis-le-Grand (1814) \\
Liceu Descartes (1848) \\
Liceu [depois] Liceu Imperial Louis-le-Grand (1849) \\
Liceu Descartes (1870) \\
Desde 1873, Liceu Louis-le-Grand. \\
\end{tabular} \\
\hline 2 & Henri IV & Meninos & $\begin{array}{c}\mathrm{V} \\
\text { Circunscrição } \\
\text { Administrativa }\end{array}$ & 1804 & $\begin{array}{l}\text { Liceu do Panthéon (1804) } \\
\text { Liceu Napoléon (1804) } \\
\text { Colégio Real Henri IV (1814) } \\
\text { Liceu Corneille (1848) } \\
\text { Liceu [depois] Liceu Imperial Napoléon (1849) } \\
\text { Liceu Corneille (1870) } \\
\text { Desde 1873, Liceu Henri IV }\end{array}$ \\
\hline 3 & Charlemagne & Meninos & \begin{tabular}{|c|} 
IV \\
Circunscrição \\
Administrativa \\
\end{tabular} & 1804 & 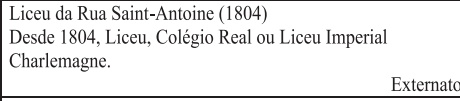 \\
\hline 4 & Condorcet & Meninos & $\begin{array}{c}\text { IX } \\
\text { Circunscrição } \\
\text { Administrativa }\end{array}$ & 1804 & $\begin{array}{l}\text { Liceu da Chaussée d'Antin (1804) } \\
\text { Liceu Bonaparte (1804) } \\
\text { Colégio Real Bourbon (1814) } \\
\text { Liceu Chaptal (1848) } \\
\text { Liceu Fourcroy (1848) } \\
\text { Liceu [depois] Liceu Imperial Bonaparte (1848) } \\
\text { Liceu Condorcet (1870) } \\
\text { Liceu Fontanes (1874) } \\
\text { Desde 1883, Liceu Condorcet }\end{array}$ \\
\hline 5 & Saint-Louis & Meninos & \begin{tabular}{|c|} 
VI \\
Circunscrição \\
Administrativa \\
\end{tabular} & 1820 & \begin{tabular}{|l|} 
Colégio Real Saint-Louis (1820) \\
Liceu Monge (1848) \\
Desde 1849, Liceu ou Liceu Imperial Saint-Louis \\
\end{tabular} \\
\hline 6 & Michelet & Meninos & VANVES & 1864 & $\begin{array}{l}\text { Inicialmente casa dos campos (1798) } \\
\text { depois anexo (1853) do Liceu Louis-le-Grand. } \\
\text { Liceu Imperial (1864) } \\
\text { Liceu do Prince-Impérial (1864) } \\
\text { Liceu Buffon (1870) } \\
\text { Liceu de Vanves (1870) } \\
\text { Desde 1888, Liceu Michelet }\end{array}$ \\
\hline 7 & Fénelon & Meninas & \begin{tabular}{|c|} 
VI \\
Circunscrição \\
Administrativa \\
\end{tabular} & 1883 & Externato \\
\hline 8 & Janson-de-Sailly & Meninos & \begin{tabular}{|c|} 
XVI \\
Circunscrição \\
Administrativa \\
\end{tabular} & 1884 & Internato \\
\hline 9 & Lakanal & Meninos & SCEAUX & 1885 & Internato \\
\hline 10 & Racine & Meninas & \begin{tabular}{|c|} 
VIII \\
Circunscrição \\
Administrativa \\
\end{tabular} & 1887 & Externato \\
\hline 11 & Molière & Meninas & \begin{tabular}{|c|} 
XVI \\
Circunscrição \\
Administrativa \\
\end{tabular} & 1888 & Externato \\
\hline
\end{tabular}

NOTA: Os liceus portaram o título de Colégios Reais de 1814 a 1848 e de liceus imperiais de 1853 a 1870. 